ASSESSING MISSOURI SOYBEAN FIELDS FOR AZOXYSTROBIN RESISTANT CERCOSPORA SOJINA

A Thesis Presented to the Faculty of the Graduate School at the University of Missouri-Columbia

In Partial Fulfillment of the Requirements for the Degree Master of Plant, Insect and Microbial Sciences

By

BRUNA MACGREGOR

Dr. Kaitlyn Bissonnette, Thesis Supervisor

July, 2021 
The undersigned, appointed by the dean of the Graduate School, have examined the thesis entitled

\section{ASSESSING MISSOURI SOYBEAN FIELDS FOR AZOXYSTROBIN RESISTANT CERCOSPORA SOJINA}

presented by Bruna MacGregor,

a candidate for the degree of Master of Plant, Insect and Microbial Sciences,

and hereby certify that, in their opinion, it is worthy of acceptance.

Assistant Extension Professor Kaitlyn Bissonnette

Associate Extension Professor Patrick Guinan 


\section{DEDICATION}

To my family, this thesis is dedicated to you. For lifting me up when I didn't believe in myself and for showing your unconditional love and support throughout this journey. To my husband Miles, thank you for not letting me give up, I would not have made it without you. 


\section{ACKNOWLEDGEMENT}

I would like to thank all the staff at the Graves Chapple Research Station and at the Delta Fisher Research Station who helped me accomplish my field research goals, I would not have made it without you. Also, I would like to thank all the amazing staff and faculty at the University of Missouri who, somehow, inspired, helped, and guided me through these 3 years. I would especially like to thank my lab crew, Susan Taylor, Daniel Sjarpe and Meghan Biggs, who helped over the years. Dr. James Schoelz, thank you for mentoring and teaching me. To my committee, Dr. Bissonnette, Dr. Guinan, and Dr. Miller, thank you for guiding me along this bumpy road. Thank you Dr. Bissonnette for being my advisor and trying your best, you were a key piece of this graduate school puzzle. Also, thank you to Missouri Soybeans and USDA NIFA for sponsoring my research. 


\section{TABLE OF CONTENTS}

LIST OF TABLES

LIST OF FIGURES viii

ABSTRACT.

CHAPTER 1. Literature Review - Cercospora sojina and a history of

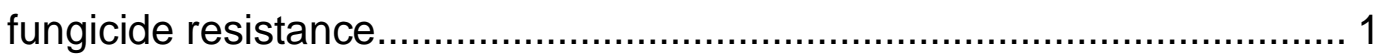

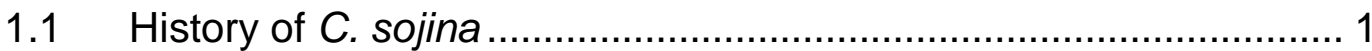

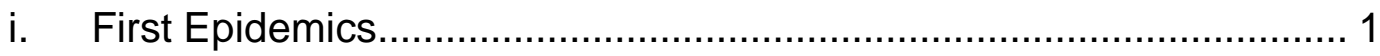

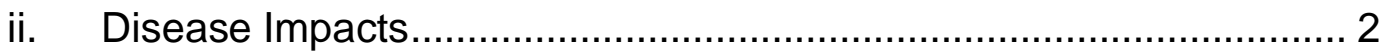

$1.2 \quad$ Background of Cercospora sojina.................................................. 3

i. Pathogen Characteristics and Life Cycle ....................................... 3

ii. How Cercospora sojina is currently managed ................................ 5

1.3 Management of Frogeye Leaf Spot …….................................... 6

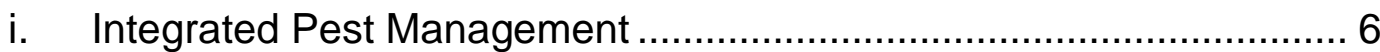

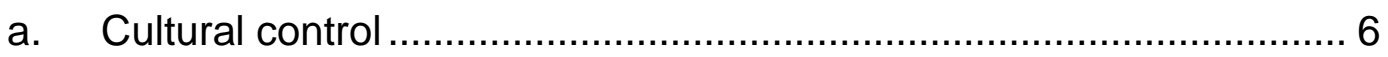

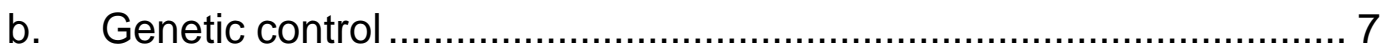

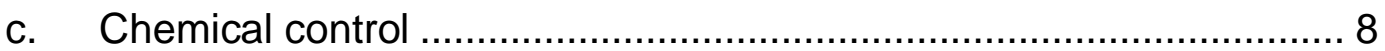

1.4 Chemical Control of FLS ........................................................ 9

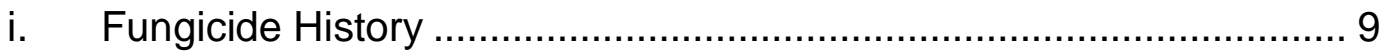

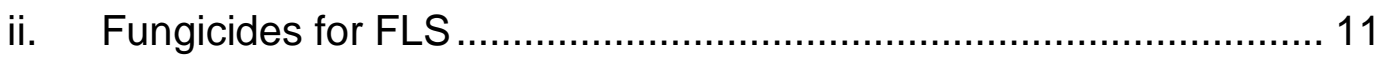

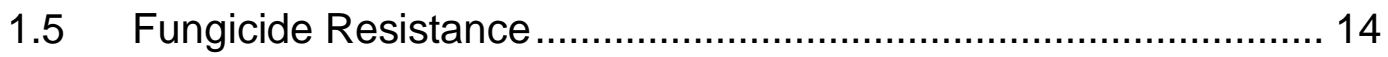




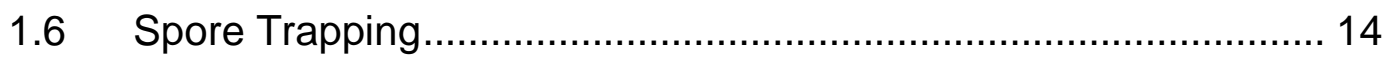

i. Fundamentals of Spore Trapping .................................................. 14

ii. Potential for New Uses ............................................................. 16

iii. How Pathogens Can Be Identified Based on DNA …...................... 16

1.7 Detecting Fungicide Resistant Cercospora sojina in Missouri....... 18

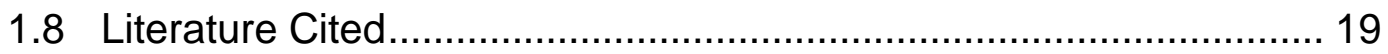

CHAPTER 2: Survey of Missouri fields for azoxystrobin resistant

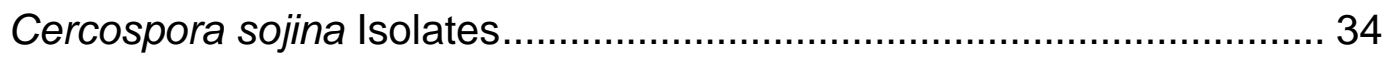

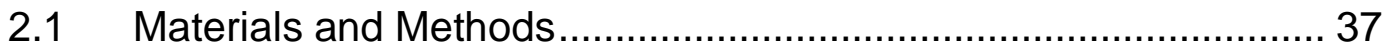

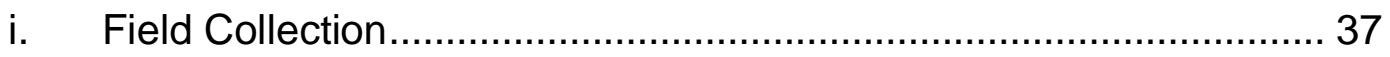

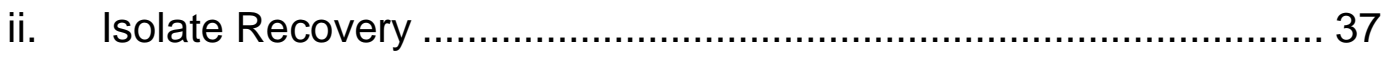

iii. Fungicide Sensitivity Bioassay .................................................... 38

iv. Identification of $C$. sojina Fungicide Resistance Through PCR ....... 40

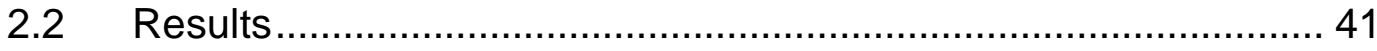

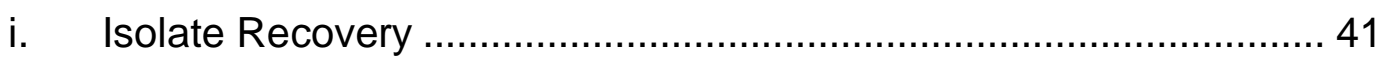

ii. DNA Identification of G143A Mutation C. sojina ............................ 42

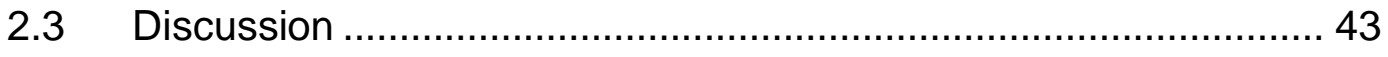

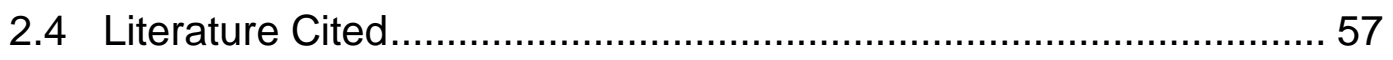

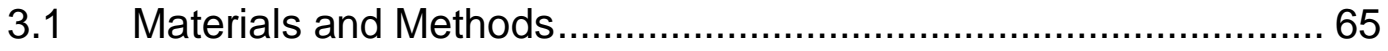

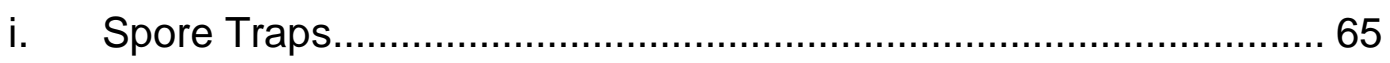

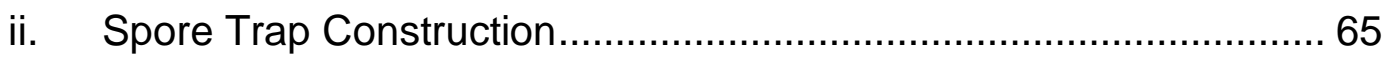

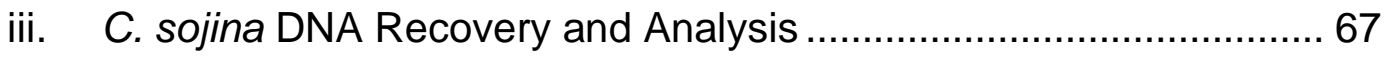




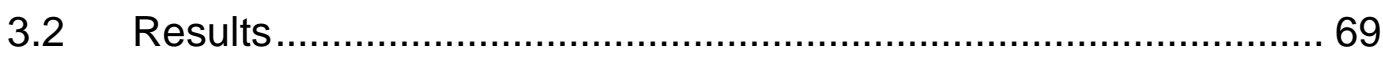

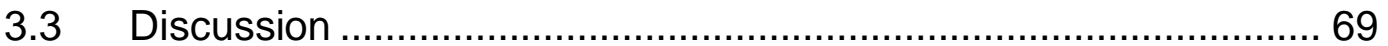

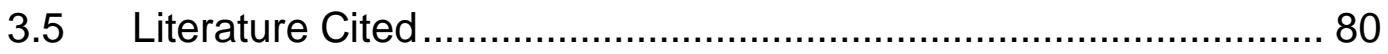




\section{LIST OF TABLES}

Table 2.1. Quantity of Cercospora sojina isolates collected during the years of 2019 and 2020 classified as resistant or sensitive to the Qol class of fungicides via fungicide sensitivity assay. An isolate was said to be fungicide resistant when growth was present in all 5 ranges of fungicide-amended PDA plates.

Table 2.2. Primers utilized for PCR to confirm the presence of Qol resistance in Cercospora sojina. Sets were selected based on primers developed by Zheng et al. (2015) which represented both the wild type and the G143A point mutation present in the mutant of the most common resistance gene in $C$. sojina. 50

Table 2.3. Percentage of Qol fungicide resistant and sensitive Cercospora sojina isolates collected per area of the state of Missouri between 2019 and 2020.

Table 2.4. DNA Sanger sequencing analysis by the University of Missouri DNA Core Facility of 84 Cercospora sojina isolates which exhibited fungicide resistance in the fungicide sensitivity assay. Primers for the wild type and G143A mutation were derived from Zheng et al. (2015). Isolates are divided into those with the wildtype sequence present, those that contained the G143A mutation, and those with an unknown mutation by area (Northwest, Southwest, Northeast,

Southeast, and Central) of Missouri. 52 
Table 3.1. Location from samples that met satisfactory levels of DNA (at least $10 \mathrm{ug} / \mathrm{mL}$ ) during the 2019 and 2020 collection season, and which spore trapping mechanism they were collected from. Where GC = Graves Chapple Research Station; BR = Bradford Research Station; DC = Delta Fisher Center Research Station. Spore trap types include: $\mathrm{P}=$ Passive; $\mathrm{SP}=$ Semi-passive; and $\mathrm{AC}=$ Active 


\section{LIST OF FIGURES}

Figure 2.1. Counties where Cercospora sojina isolates were collected in Missouri during the 2019 and 2020 growing seasons.

Figure 2.2. List of counties where Qol fungicide-resistant Cercospora sojina isolates were confirmed in Missouri during the 2019-2020 growing seasons.

Figure 2.3. Average temperature in Missouri between June $1^{\text {st }}, 2019$ to August $31^{\text {st }}, 2019$ and how it differs from the 1981-2010 normal average. Online publication by Midwestern Regional Climate Center (MRCC https://mrcc.illinois.edu 2021).

Figure 2.4. Average precipitation, shown in inches, in Missouri between June $1^{\text {st }}, 2019$ to August $31^{\text {st }}, 2019$ and how it differs from the $1981-2010$ normal average. Online publication by Midwestern Regional Climate Center (MRCC https://mrcc.illinois.edu 2021)

Figure 2.5. Average temperature, shown in Fahrenheit, in Missouri between June $1^{\text {st }}, 2020$ to August $31^{\text {st }}, 2020$ and how it differs from the 19812010 normal average. Online publication by Midwestern Regional Climate Center (MRCC https://mrcc.illinois.edu 2021). 55 
Figure 2.6. Average precipitation, shown in inches, in Missouri between June $1^{\text {st }}, 2020$ to August $31^{\text {st }}, 2020$ and how it differs from the $1981-2010$ normal average. Online publication by Midwestern Regional Climate Center (MRCC https://mrcc.illinois.edu 2021).

Figure 3.1. Distribution of spore traps deployed in Missouri. Fisher Delta Research Center (DC), Portageville, MO - circle; Bradford Research Center (BR), Columbia, MO - triangle; Graves-Chapple Research Center (GC), Rock

Port, MO - square. 73

Figure 3.2. A) the Modified Gadoury and MacHardy sampler was built in PVC and consisted of: (a) a PVC body, (b) a collection head - shown in detail on Fig. 8B. Both the PVC fin (c) and tail (d) were added to improve the stability of the sampler and improve sampler movement by wind. The computer fan (e) acted as a turbine by sucking air through collection hole (f). Metal ' $T$ ' post (g) was used for trap sustainability. Figure 8.B) shows collection head with Dickson rotating mechanism inside (a) the collection head. Arrow (b) shows where lowpressure tape was secured.

Figure 3.3. A side view $(A)$ and back view (B) from the SP spore trap, built from PVC pipe containing a fin (a), PVC tube as body (b), opening for the glass slide to collect spores (c), metal mesh (d) to prevent foreign material from entering, supportive PVC tube (f), and PC fan in the background (e). The glass slide (g) had two layers of tape, first a layer of double-sided tape followed by a layer of a low-pressure tape. 
Figure 3.4. Passive spore trap containing a PVC body (a), PVC fin, and funnel in the background (b), directing wind to a glass slide that has two layers of tape, first a layer of double-sided tape followed by a layer of a low-pressure tape connected to metal mesh via Velcro tape (c), metal mesh (d) secured by a metal hose clamp (e)

Figure 3.5. Agarose gel showing PCR results from SP spore trap samples collected from the GC location where the red circle symbolizes the DNA ladder and the red star is the positive control.

Figure 3.6. $A$ and $C$ represent 2019 average temperature, shown in Fahrenheit, and precipitation in Missouri between June 1st and August 31st and how it differs from the 1981-2010 normal average; B and D represent 2020 average temperature, shown in Fahrenheit, and precipitation in Missouri between June 1st and August 31st and how it differs from the 1981-2010 normal average. Online publication by Midwestern Regional Climate Center. (MRCC https://mrcc.illinois.edu 2021). 


\begin{abstract}
Successful management of Cercospora sojina, the causal agent of frogeye leaf spot, can be achieved through utilizing resistant varieties and fungicide applications. Fungicides in the quinone outside inhibitor (Qol) class are most effective in controlling $C$. sojina in the field. Unfortunately, azoxystrobin fungicide-resistant isolates of $C$. sojina have been recovered in many soybean growing areas of the U.S. Fungicide-resistant isolates of $C$. sojina were first detected in 2011 and 2012 in two counties in southeast Missouri, but no further assessment was conducted. In this study, 121 isolates were collected from 15 surveyed counties between 2019 and 2020 in an effort to understand the geographical distribution of fungicide-resistant $C$. sojina. Isolates were collected from fields based on the presence of frogeye leaf spot symptoms. Samples were brought to the laboratory and isolates were recovered from individual lesions. A fungicide sensitivity bioassay was conducted to determine which isolates were resistant to the Qol class of fungicides. The fungicide sensitivity bioassay consisted of full-strength PDA amended with technical grade azoxystrobin at five different concentrations and a no fungicide control. Out of 121 isolates, 81 were fungicide-resistant representing 13 of the 15 Missouri counties included in the survey. Notably, the northwest corner of Missouri had the highest concentration of fungicide-resistant isolates, consistent with the recent recovery of fungicideresistant $C$. sojina isolates in lowa and Nebraska. The widespread recovery of fungicide-resistant $C$. sojina in multiple counties throughout Missouri provides new insight into disease management in the state.
\end{abstract}


CHAPTER 1. Literature Review - Cercospora sojina and a history of fungicide resistance

Frogeye leaf spot (FLS) is an ongoing threat to United States soybean production since this pathogen was first discovered in South Carolina in 1924 (Melchers 1925). Cercospora sojina K. Hara, the pathogen associated with FLS, is a fungal disease affecting soybeans (Glycine $\max (\mathrm{L}$.) Merr.). FLS is primarily a foliar disease but can also affect other portions of the soybean plant, such as stems, pods, and even seeds (Grau et al. 2004; Standish et al. 2015). Understanding the history and life cycle of $C$. sojina is important to understanding how to control it.

\subsection{History of C. sojina \\ i. First Epidemics}

The first reports of FLS date back to 1915 in Japan and 1924 in the United States in the state of South Carolina (Lehman 1928; Melchers 1925; Standish et al. 2015). In 1925, FLS was then detected in Mississippi and Louisiana (Haskell 1926; Lehman 1928; Standish et al. 2015). Since then, FLS has spread throughout the southern soybean-producing states within the U.S. (Akem 1995; Athow and Probst 1952; Phillips 1999; Ploper et al. 2001; Wrather et al. 2010). The preferred conditions for the perpetuation of the $C$. sojina pathogen may explain why FLS has largely been a problem in the southern U.S. (Mengistu 2014; Walker et al. 1994). C. sojina thrives well when temperatures are between 
75-and 80 -degrees Fahrenheit with relative humidity of $90 \%$ or higher (Cruz and Dorrance 2009; Lin and Kelly 2018). Under these conditions, sporulation can occur within 48 hours after symptoms appear (Mian et al. 2008).

The lack of hardiness to survive the northern winter temperatures is an additional factor to why FLS is predominantly found in the southern states (Mengistu 2014; Walker et al. 1994). As climatic conditions have changed, FLS severity has been increasing in the Midwest and other northern states. Other states include: Illinois, Kentucky, Tennessee, Alabama, Arkansas, Mississippi, Missouri, Louisiana (Bradley et al. 2013; Mengistu et al. 2014), lowa, Wisconsin, Ohio, (Mengistu et al. 2002; Cruz and Dorrance 2009; Yang et al. 2001; Mengistu et al. 2014), Delaware, North Carolina, and Virginia (Phillips 1999).

ii. Disease Impacts

The leading cause of yield losses in fields infected with the pathogen $C$. sojina are defoliation and loss of green leaf area due to disease lesions decreasing the active photosynthetic area (Akem and Dashiell 1994; Mengistu 2014). It is estimated that over a 10-year period, yield losses attributed to FLS in U.S. soybean producing states increased over tenfold, increasing from 23,000 metric tons lost in 1996 to close to 257,000 metric tons lost in 2007 (Wrather and Koenning 2009; Koenning and Wrather 2010; Standish et al. 2015). In the seven years from 2007 to 2014, losses again doubled from 257,000 metric tons in 2007 to 493,880 metric tons in 2014 (Allen et al. 2017; Zhang et al. 2018). When conditions are right, FLS has the potential to cause substantial yield loss in soybean producing areas of the U.S. and Canada. 


\subsection{Background of Cercospora sojina}

i. Pathogen Characteristics and Life Cycle

Cercospora sojina is a hemi-biotrophic fungus in the phylum Ascomycota.

Once infection is established in soybean tissue, hyaline conidia are produced on conidiophores protruding from the leaf surface (Lin and Kelly 2018). Hyaline conidia are both the primary and secondary inocula for this pathogen and ensure pathogen survival throughout the season (Mian et al. 2008).

Conidia are disseminated from the conidiophores by continuous growth of conidia on the terminal end of the conidiophores which are dispersed by wind (Mian et al. 2008). Spore germination on leaf tissue is favored by warm temperatures between 75- and 80-degrees Fahrenheit (Cruz and Dorrance 2009), and high relative humidity of $90 \%$ or greater (Phillips 1999; Mengistu et al. 2014; Lin and Kelly 2018), or free moisture. After infection, lesions can take 7 to 14 days to appear on young tissue (Mengistu et al. 2014). Lesions are circular to angular and can vary from $1 \mathrm{~mm}$ to $5 \mathrm{~mm}$ in diameter (Cruz and Dorrance 2009). FLS lesions can appear water-soaked with light gray centers and have dark reddish-brown borders (Phillips 1999; Standish et al. 2015). As disease progresses, lesions expand and become irregular in shape (Standish et al. 2015). As lesions on the leaf surface continue to form, they coalesce and once lesion coverage reaches $30 \%$ or more of the leaf area, leaves can prematurely fall from the plant. If leaf drop occurs early in the developmental growth stages or during grain fill, FLS can lead to low seed weight (Phillips 1999; Mian et al. 2008). The pathogen also can infiltrate pods and infect seeds (Mian et al. 2008). 
If infected seeds germinate, conidia found in lesions on the cotyledons serve as primary inoculum and infect expanding leaves.

FLS is a polycyclic disease in which the production of inoculum, infection, and symptom development does not stop if environmental conditions continue to be favorable throughout the growing season. These characteristics also influence the amount of disease present (Lin and Kelly 2018). The life cycle of FLS is presented below:

1. During the colder months, $C$. sojina overwinters as mycelia in infected soybean seeds and on residue at the soil surface (Lin and Kelly 2018). Once on debris, C. sojina can survive for up to 2 years as fruiting bodies, ascocarps designed for survival of its sexual spores (Cruz and Dorrance 2009).

2. As the temperatures reach $75-80^{\circ} \mathrm{F}$ and relative humidity increase, the overwintering fruiting bodies release ascospores that are carried by wind, water, insect contact, humans, shared field machinery, and animals until these ascospores land on soybean tissue where they are able to germinate and infect.

3. After infection occurs, lesions can become visible within 7 to 14 days. Young and emerging leaves are more susceptible to infection, while older leaves are less vulnerable (Lin and Kelly 2018). As lesions mature, they produce conidia that serve as secondary inoculum.

4. Under ideal conditions, the pathogen will continue to produce secondary inoculum which increases the number of infected leaves and 
plants, leading to higher disease incidence and severity (Lin and Kelly 2018).

5. Infected soybean residue left in the field after harvest combined with mild winter temperatures and conservation tillage practices allow for the survival of inoculum for disease to continue in the following season (Lin and Kelly 2018).

Cercospora sojina is a sexually recombining pathogen, capable of producing heterozygous spores which influences the genetic variability of the pathogen (Zhang and Bradley 2017). According to Bradley et al. (2012), C. sojina isolates collected across the globe demonstrate a high level of genetic diversity with no association among themselves. Among the 12 different races of $C$. sojina tested by Mian et al. (2008), races 3 and 5 comprise the largest group that cause FLS in the U.S. Of primary concern is the increased risk of genetic mutation in $C$. sojina due to its high genetic diversity resulting in mutations in the genes capable of conferring resistance to fungicides in the Quinone outside Inhibitor class.

ii. How Cercospora sojina is currently managed

Soybean plants infected with $C$. sojina can undergo premature defoliation which negatively affects soybean yields (Wrather et al 2010; Zeng et al. 2015). Current practices recommended to manage FLS include using resistant cultivars, applying foliar fungicides, crop rotation, and planting pathogen-free seeds (Phillips 1999).

Using resistant varieties to manage FLS is the best and easiest method to manage $C$. sojina; however, some resistant varieties are only partially resistant 
and will not entirely prevent infection (Bradley et al. 2016). As the pathogen can overwinter on soybean residue, rotating to nonhost crops, planting certified, pathogen-free seed, and adopting cultural practices can be beneficial to reduce disease development. In addition, well-timed foliar fungicide applications can effectively control FLS (Bradley et al. 2016) and are one of the most utilized tools against FLS in the southern U.S. The most effective are fungicides in the Qol class (Dorrance et al. 2010; Nelson et al. 2010; Zeng et al. 2015). Often just a single management strategy is not employed, multiple management strategies are used.

\subsection{Management of Frogeye Leaf Spot}

i. Integrated Pest Management

In plant pathology the optimum conditions for disease development are often associated with the disease triangle (Stevens 1960; Francl 2001). The disease triangle is a model to demonstrate the interaction between the pathogen, host and environment, a host's susceptibility to a pathogen, inoculum with parasitic potential, and a conductive environment to both parasite and infection (Scholthof 2007; McNew 1960).

An integrated and diversified approach towards the management of (FLS) is the most appropriate way to address a $C$. sojina infection or the threat of one. An integrated management strategy includes cultural practices, utilization of resistant varieties, and the use of chemical control when necessary.
a. Cultural control 
Cultural practices, or cultural control, is the act of manipulating the agroecosystem to create a less desirable place for the establishment, development and proliferation of pest populations (Dufour 2001; Gabrys and Kordan 2012). Cultural practices include but are not limited to: planting certified disease-free seed, maintaining an effective water management program, and removing crop residues by plowing (Williams et al 2017). For FLS management, crop rotation and tillage can effectively reduce the pathogen population from season to season (Lin and Kelly 2018). A two-year crop rotation away from soybean can effectively reduce inoculum levels. According to Lin and Kelly (2018), tillage alone is not enough to reduce disease severity levels, but has shown to improve the efficacy of fungicide applications when compared to no-till plots in a side-by-side comparison. Planting pathogen-free seed prevents some primary inoculum from entering the field, especially in areas where the disease may not yet be present; however, based on current production practices, residue plays a significant role in primary inoculum production.

b. Genetic control

The most effective and economical management strategy for FLS is host resistance (Lin and Kelly 2018). There are three genes named by the Soybean Genetics Committee known to confer resistance to infection by C. sojina: Rcs1, $R c s 2$, and Rcs3. When it comes to $C$. sojina, there are multiple pathogen races which can be distinguished by their ability to infect different soybean varieties that have different resistance genes. The gene Rcs3 is known to confer resistance to all pathogen races currently present in the U.S. 
The first gene identified was Rcs1 in "Lincoln" and which is resistant to race 1 of $C$. sojina (Athow and Probst 1952; Mian et al. 2008). The gene Rcs2 was derived from "Kent" and confers resistance to C. sojina race 2 (Athow et al. 1962; Mian et a. 2008). The most widely utilized gene is Rcs3, derived from "Davis" and it is resistant to race 5 and all other known races of $C$. sojina in the U.S. (Phillips and Boerma 1982; Mian et al. 2008) and Brazil (Yorinori 1992). Pace et al. (1993) discovered other dominant genes in cultivars "Ransom", "Stonewall", and "Lee" as also having resistance to race 5, and that each of them is nonallelic to Rcs3 and to each other (Mian et al. 2008). In maturity groups MG V to VIII, FLS-resistant soybean cultivars were specially developed utilizing the resistance gene Rcs3 (Mian et al. 2008). As genetic resistance is deployed in the field, disease incidence levels decrease (Damicone 2017) and the need for multiple fungicide applications is reduced.

\section{c. Chemical control}

To manage FLS, foliar applications of fungicides in the Qol class are effective when applied before infection appears to protect new growth during conductive weather periods (Lin and Kelly 2018). Research suggests fungicide applications performed between full bloom (R2) and beginning seed (R5) stages provide the best economical response (Lin and Kelly 2018). Tillage practices combined with a fungicide application have shown to reduce disease severity while increasing yield (Lin and Kelly 2018).

When implementing a fungicide application program, disease efficacy and fungicide resistance management should be taken in consideration. Once a 
monitoring program is in place, the number of applications and dosage are the next phase to consider. The greater the number of applications and higher the dosage, the greater the expected increase in pressure selection for fungicide resistance development (van den Bosch et al. 2011; van den Berg et al. 2016). An effective fungicide application program needs to be combined with an effective fungicide resistance management plan. By avoiding the use of single mode of action fungicides, limiting applications and optimizing dosages, fungicide resistance can be managed (Brent and Hollomon 2007).

\subsection{Control of FLS}

i. Fungicide History

Fungicides are most commonly applied as either seed applications or as a direct contact application on crops (Zubrod et al. 2019). Direct applications are most often applied as a preventive measure rather than for their curative properties as curative applications increase the risk of fungicide resistance.

Currently, fungicide applications are considered crucial for global food security (Strange and Scott 2005; Zubrod et al. 2019). For this reason, fungicide use is predicted to increase as changes in climate occur, fungicide resistance develops, and invasive fungal species appear (Fisher et al. 2012; Hakala et al. 2011; Boxall et al. 2009; Zubrod et al. 2019). The U.S. alone represents $80 \%$ of the total fungicides applied on field crops in the North America, which only account for $10 \%$ of the total agrichemical applications made in the U.S., or about 15\% of the applications for soybeans (Zubrod et al. 2019; NASS 2019). 
The development of chemical control for field crops is costly. Early products were reserved for crops with a higher economic and market value such as vegetables, fruits and ornamental crops. Field crops were treated for pests using cultural practices. As society began to rely more in agriculture with the shift from family farming into monoculture, pests started to be an issue that affected the agricultural economy (Wetzel et al. 2016; University of California - Davis 2016). Public agencies started to sponsor the development of breeding programs to promote host resistance development contributing to the improvement of many cultivated field crops in the country (Apple 1977). By the 1980s, research into new agrichemicals continued and the use of chemical control in agriculture became widespread over a broad acreage as more single mode of action chemicals were released (Unsworth 2010).

In the 1990s, researchers were dedicated to finding new fungicides. Research focused on developing new fungicides derived from existing fungicide classification groups for better pathogen selectivity and toxicology profiles (Unsworth 2010). As a result of these efforts, fungicides such as the Qols and azoles were discovered and launched for public use. According to National Agricultural Statistics Service (NASS) survey reports, a change in fungicide use in field crops began to occur in the U.S. in the early 2000 s. Based on data from the Agricultural Chemical Usage database from NASS, only $7 \%$ of the total soybean acreage in 2002 were treated with azoxystrobin (NASS 2002). By 2004, the acreage of soybean treated with azoxystrobin had increased to 13\% (NASS 
2004). The current soybean acreage treated with all fungicides (all classes and chemicals) in the U.S. is 15\% (NASS 2019).

Depending on environmental conditions and field history, more than one fungicide application may be necessary in a field, especially if conditions are favorable for continued pathogen development or there is an increased likelihood of overwintering as disease amounts could be elevated as the pathogen is already present in the field. If this is the case, the risk of fungicide resistance also may increase.

\section{ii. $\quad$ Fungicides for FLS}

Fungi and fungal-like organisms are the major organisms responsible for plant diseases, as over 8,000 species from the Kingdom Fungi can cause disease when conditions are optimal (Williams et al. 2017). In order to have symptom expression, all the optimal environmental conditions must occur, there must be a susceptible host, and the pathogen must be present.

The third component of an integrated disease management strategy to reduce FLS impacts includes the application of a foliar fungicide. It wasn't until 1996 when chemicals in the strobilurin class, or Quinone outside Inhibitor Fungicide Resistance Action Committee (FRAC) group 11 were released. This class includes chemicals like azoxystrobin, pyraclostrobin and trifloxystrobin (Morton and Staub 2008). Fungicide group 11 is the second largest chemistry group of fungicides, used in both cereals and soybeans. Fungicides in the strobilurin group are most effective in controlling the $C$. sojina pathogen and are 
widely used for the control of frogeye leaf spot (Dorrance et al. 2010; Nelson et al. 2010; Zeng et al. 2015).

The Qols are single mode of action fungicides that inhibit plant pathogens by impeding a pathogen's ability to produce energy. Inhibition occurs by the blockage of electron transference at the "Quinone outside" site of the cytochrome $b$ (cyt $b$ ) gene, between cyt $b$ and cytochrome c1 (Bartlett et al. 2002; Standish et al. 2015) at complex III in electron transport chain. Qols are active against a broad range of fungal pathogens including the three important genera of pathogens: ascomycetes, basidiomycetes and oomycetes. Qol fungicides are most effective when applied as preventative fungicides, as they inhibit pathogen respiration thereby averting pathogen infection (Mueller et al. 2013).

The Qol fungicide azoxystrobin is locally systemic and has a translaminar movement which allows it to flow from the initial deposition point on the waxy cuticle through the leaf blade (Vincelli 2002). However, the translaminar movement expressed by the Qol fungicides may take multiple days which can delay full leaf protection against pathogens (Vincelli 2002). According to Mueller et al. (2004) if Qol fungicides are applied up to 3 days after pathogen inoculation fungal diseases like FLS can still be controlled. In the same study, an application more than 3 days after infection resulted in a decrease Qol fungicide efficacy.

When foliar applied, fungicides in the Qol class are an important tool for managing FLS (Standish et al. 2015). Fungicides applied between full bloom (R2) and beginning seed (R5) have been shown to reduce FLS incidence and severity when applied before infection occurs. Due to the continued application of 
fungicides and sexual recombination by the pathogen, point mutations occur in the cyt $b$ gene (Fernández-Ortuño et al. 2012; Standish et al. 2015). Such point mutations allow for the fungus to thrive by overcoming the pathway that inhibits cellular respiration (Anke 1995; Balba 2007; Bartlett et al. 2002; Standish et al. 2015).

When implementing a fungicide application program, disease efficacy and resistance management should be taken in consideration. Disease efficacy refers to measuring the ability of the pathogen to overcome chemical and biocontrol agents especially in relation to the durability of chemical control programs as fungicide resistance has become more frequent in major fungal pathogenic populations (Brent and Hollomon 2007; Bardin et al. 2015). Resistance management focuses on reducing selection pressure that an application program and the fungicides used have on a pathogen (van den Berg et al. 2016). Number of applications and dosage are important factors to be taken into consideration as more applications and higher dosages are expected to increase the selection toward fungicide resistant pathogens (van den Bosch et al. 2011, 2014a, 2014b; van den Berg et al. 2016). An effective fungicide management program includes fungicide resistance management (van den Berg et al. 2016).

Qol fungicides have a "high-risk" of resistance development as they target a specific site in fungal biochemical pathways. Fungicide resistance in $C$. sojina is associated with three mutation points which are located in the cytochrome $b$ complex (Zeng et al. 2015). The three mutation points are: a change from glycine to alanine at codon 143 (G143A); a change from phenylalanine to leucine at 
codon 129 (F129L); and a change from glycine to arginine at codon 137 (G137R). Out of the three mutation points, G143A not only grants the highest level of resistance but is also the most common mutation in isolates of $C$. sojina recovered from the field (Fisher and Meunier 2008; Zeng et al. 2015).

\section{$1.5 \quad$ Fungicide Resistance}

There are two types of fungicide resistance: quantitative and qualitative. Fungal pathogens with quantitative resistance can often still be controlled with higher fungicide rates or more frequent applications of the fungicide, within label limits (Vincelli 2002). Qualitative fungicide resistance occurs when a point mutation results in a pathogen is no longer having sensitivity to a fungicide active ingredient or class of fungicides (Vincelli 2002). The Qol-resistant C. sojina isolates are an example of qualitative fungicide resistance.

The Qol group of fungicides are site-specific, meaning theses fungicides interfere with a specific biochemical site within the fungal cell (Vincelli 2002). As pathogen control is specific to one site, just one mutation in the pathogen can result in a fungicide-resistant strain, which gives this class of fungicides the classification of "high-risk" for resistance development (FRAC 2014). When a high-risk fungicide is applied to a pathogen with high mutation rates like $C$. sojina. Repeat fungicide applications and the application of high-risk fungicides also can increase selection pressure on the pathogen which influences the fungicide resistance development (Zeng et al. 2015).

\subsection{Spore Trapping}

i. Fundamentals of Spore Trapping 
Wind is a crucial component for the survival and spread of pathogens and is especially important for plant pathogenic fungi (Brown and Hovmøller 2002). The transport of plant pathogenic fungal spores hundreds and even thousands of miles from their original source allows a pathogen to colonize new geographies (Brown and Hovmøller 2002; Gage et al. 1999). Pathogens like C. sojina are capable of spreading across wide geographies due to the large quantity of spores produced and their airborne dispersal.

For field crop pathogens like fungi, monitoring spore dispersal through spore trapping is one mechanism to improve disease management strategies (Simberloff 2003; Rejmanek and Pitcairn 2003; Parnell et al. 2015). When a mechanism like spore trapping is being implemented, the way the device samples air is as important as device positioning and should be aligned with the dynamics of the pathogen (Jackson and Bayliss 2011; Parnell et al. 2015). When it comes to sampling spores of airborne pathogens, spore traps are a useful tool. It is important to keep in mind that if inadequate technology is implemented, disease surveillance programs may be ineffective (Kalaris et al. 2014).

Current disease modeling provides only a prediction of pathogen spread in a given area; spore traps are the only way to verify the presence of a pathogen before symptoms are visible (Jackson and Bayliss 2011). Spore traps vary based on their suitability and practically of implementation, as some may only detect at a specific density while others can detect spores at lower concentrations. Active spore traps that pull in air into the apparatus provide more effective sampling 
than passive traps which rely on natural air currents and can be more useful when developing disease management strategies (Savage et al. 2012).

ii. Potential for New Uses

Spore traps can be classified as active, passive, semi-passive and ionic (Jackson and Bayliss 2011). Active traps (volumetric or cyclonic) use a motor to move the sampling head and do not depend on wind to rotate the collection compartment. Spores are more effectively collected in active traps than passive traps as they actively intake air into the trap head. In contrast, passive spore traps do not require the use of motor or batteries, but rely on wind for spore intake, also making them less prone to mechanical failure.

Spore traps have some limitations, such as maintaining spore viability and inconsistency during extreme weather changes ( $\mathrm{Li}$ et al. 2010; Jackson and Bayliss 2011). These limitations can make data collected from spore traps unreliable and reduce the confidence levels of these mechanisms (Jackson and Bayliss 2011). As spore traps start to be used more and their limitations overcome, confidence and reliability will increase therefore validating the data generated by them. That said, carefully choosing the right spore trap model based on known environmental conditions of the geography can help increase the reliability of spore traps.

iii. How Pathogens Can Be Identified Based on DNA

Plant pathology would not be the same without the proper identification of the causal agent of disease (McCartney et al. 2003). With spore trapping, different microscopy techniques can be used for spore identification, (Lacey and 
West 2006) but a proper diagnosis of spore material is often difficult (Allitt, 1979; Lacey and West 2006). DNA-based and immunological methods are becoming more common (Sholberg et al. 2005; Jackson and Bayliss 2011) as these methods have become faster than traditional culturing techniques and microscopy (Louws et al. 1999; Martin et al. 2000; Ward et al. 2004; Sholberg et al. 2005). For the completion of molecular work, pathogenic DNA has to be extracted from the sample. Pathogenic fungal DNA can be extracted by a few different methods. Various DNA kits to recover genomic DNA are commercially available and published extraction protocols can improve fungal DNA recovery (Fredricks et al. 2005).

Using molecular methods such as polymerase chain reaction (PCR) amplification of nucleic acid sequences or real-time, quantitative PCR (qPCR) gives more accurate and faster results when compared to traditional identification methods (McCartney et al. 2003; Quesada et al. 2018). PCR-based detection is fast and accurate even when small quantities of DNA are present (Glick and Pasternack 2003), as PCR amplifies small portions of DNA utilizing DNA primers coded to a target sequence in the genomic DNA of interest. The process of PCR separates DNA's double strand into single strands and uses Taq polymerase synthesis to build two new strands, using the original strands as a template $(\mathrm{NIH}$ 2020). The described process results in new DNA copies containing an old and a new strand. The process is repeated between 30 to 40 times to ensure enough DNA material is available for genetic analysis processes. The specificity of DNA 
identification is reliant upon the accuracy of the primers used, as they can have a target ranging from the Kingdom Fungi to specific fungal species.

\subsection{Detecting Fungicide Resistant Cercospora sojina in Missouri}

Fungicide resistance was first detected in Missouri between 2011 and 2012 with two isolates of Qol-resistant $C$. sojina were recovered in the southeastern portion of the state (Zhang et al. 2018). Since then, no further surveys have been conducted or isolates have been identified in the state. However, five out of the eight states that border Missouri have had a positive confirmation of the presence of fungicide resistant isolates of $C$. sojina since 2012 (Zhang et al. 2018). According to the most recent studies of fungicide resistant $C$. sojina isolates, the latest state to detect resistant isolates was lowa in 2017 (Zhang et al. 2018). With fungicide resistance now detected in fields of the state to our immediate north, now is a critical time to assess the current distribution of $C$. sojina isolates resistant to Qol fungicides in Missouri.

The objectives of this study were to: i.) Assess current distribution of $C$. sojina Qol resistant isolates in Missouri; and ii.) Test effectiveness of spore traps for tracking air borne fungal pathogens. As a result of this study, educational programs focused on fungicide resistance management can be developed, while focusing on the implementation of integrated pest management tactics on areas where resistance is not yet detected. In addition, by utilizing spore trapping technology, there is the potential to improve disease management strategies, enhance forecasting models, and reduce fungicide use. 


\subsection{Literature Cited}

Akem, C.N. 1995. The effect of timing of fungicide applications on control of frogeye leaf spot and grain yield of soybeans. Eur. J. Plant Pathol. 101:183-187.

Akem, C.N., and Dashiell, K.E. 1994. Effect of planting date on severity of frogeye leaf spot and grain yield of soybeans. Crop Prot. 13:607-610

Allen, T.W., Bradley, C.A., Sisson, A.J., Byamukama, E., Chilvers, M.L., Coker, C.M., Collins, A.A., Damicone, J.P., Dorrance, A.E., Dufault, N.S., Esker, P.D., Faske, T.R., Giesler, L.J., Grybauskas, A.P., Hershman, D.E., Hollier, C.A., Isakeit, T., Jardine, D.J., Kelly, H.M., Kemerait, R.C., Kleczewski, N.M., Koenning, S.R., Kurle, J.E., Malvick, D.K., Markell, S.G., Mehl, H.L., Mueller, D.S., Mueller, J.D., Mulrooney, R.P., Nelson, B.D., Newman, M.A., Osborne, L., Overstreet, C., Padgett, G.B., Phipps, P.M., Price, P.P., Sikora, E.J., Smith, D.L., Spurlock, T.N., Tande, C.A., Tenuta, A.U., Wise, K.A., and Wrather, J.A. 2017. Soybean yield loss estimates due to diseases in the United States and Ontario, Canada from 2010 to 2014. Plant Health Prog. 18:19-27.

Allitt, U. 1979. The visual identification of airborne fungal spores. Proceesdings of the $1^{\text {st }}$ international conference on aerobiology, august 1978, Berichte 5/79, 139-143, Eric Schimidt Verlag, Berlin.

Anke, T. 1995. The antifungal strobilurins and their possible ecological role. Can J. Bot. 73:940-945. 
Apple, J.L. 1977. 'The Theory of Disease Management' in: Plant Pathology: An Advancement Treatise, Vol. 1, eds James G. Horsfall and A.E. Dimond. Academic Press, NY. Pages 79-99.

Athow, K.L., and Probst, A.H. 1952. The inheritance of resistance to frogeye leaf spot of soybeans. Phytopathology 42:660-662.

Athow, K.L., Probst, A.H., Kartzman, C.P., and Laviolette, F.A. 1962. A newly identified physiological race of Cercospora sojina on soybean. Phytopathology 52:712-714

Balba, H. 2007. Review of strobilurin fungicide chemicals. J.Environ. Sci. Health B. $42: 441-451$

Bardin, M., Ajouz, S., Comby, M., Lopez-Ferber, M., Graillot, B., Siegwart, M., and Nicot, P.C. 2015. Is the efficacy of biological control against plant diseases likely to be more durable than that of chemical pesticides?. Front Plant Sci. 6:566

Bartlett, D.W., Clough, J.M., Godwin, J.R., Hall, A.A., Hamer, M., and ParrDobrzamski, B. 2002. The strobilurin fungicides. Pest Manag. Sci. 58:649662 
Boxall, A. B., Hardy, A., Beulke, S., Boucard, T., Burgin, L., Falloon, P. D., Haygarth, P. M., Hutchinson, T., Kovats, R. S., Leonardi, G., Levy, L. S., Nichols, G., Parsons, S. A., Potts, L., Stone, D., Topp, E., Turley, D. B., Walsh, K., Wellington, E. M., Williams, R. J. 2009. Impacts of climate change on indirect human exposure to pathogens and chemicals from agriculture. Environ. Health Perspect., 117 (4), 508- 514, DOI:

\subsection{9/ehp.0800084}

Bradley, C.A., Chilvers, M., Freije, A., Giesler, L., Mueller, D., Sikora, E., Sisson, A., Smith, D., Tenuta, A., and Wise, K. 2016. Frogeye leaf spot. Soybean Disease Management. Crop Protection Network CPN-1017

Bradley, C.A., Wood, A., Zhang, G.R., Murray, J.E.D.V., Phillips, D.V., Ming, R. 2012. Genetic diversity of Cercospora sojina revealed by amplified fragment length polymorphism markers. Can. J. Plant Pathol. 34, 410-416

Bradley, C.A., Zhang, G., Chapara, V., Ming, R., Zeng, F., Young, H., Kelly, Y.H., and Newman, N. 2013. Update on detection and management of Qol fungicide resistant Cercospora sojina, the causal agent of frogeye leaf spot in soybean. Proc. 2013. SSDW Meeting. Pensacola, FL.

Brent K.J., and Hollomon D.W., 2007. Fungicide Resistance in Crop Pathogens: How Can it be Managed? Bristol, UK. Fungicide Resistance Action Committee.

Brown, J.K.M, and Hovmøller, M.S. 2002. Aerial dispersal of pathogens on the global and continental scales and its impact on plant disease. Science. Vol. 297; 5581:537-541. Doi: 10.1126/science.1072678 
Cruz, C.D., and Dorrance, A.E. 2009. Characterization and survival of Cercospora sojina in Ohio. Plant Health Progress doi:10.1094/PHP-20090512-03-RS

Damicone, J. 2017. Fungicide resistance management. Oklahoma Cooperative Extension. Fact Sheet F-7663. Online publication: http://pods.dasnr.okstate.edu/docushare/dsweb/Get/Rendition-3508/F7663web.pdf

Deising, H.B., Reimann, S., and Pascholati, S.F. 2008. Mechanisms and significance of fungicide resistance. Braz. J. Microbiol. 39(2): 286-295

Dorrance, A.E., Cruz, C., Mills, D., Bender, R., Koenig, M., LaBarge, G., Leeds, R., Mangione, D., McCluer, G., Ruhl, S., Siegrist, H., Sundermeier, A., Sonnenberg, D., Yost, J., Watters, H., Wilson, G., and Hammond, R.B. 2010. Effect of foliar fungicide and insecticide applications on soybeans in Ohio. Online publication. Plant Health Prog. 10.1094/PHP-2010-0122-01RS

Dufour, R. 2001. Biointensive integrated pest management. Online publication http://www.attra.orh/attrapub/ipm.html.

Fernández-Ortuño, D., Chen, F., and Schnabel, G. 2012. Resistance to pyraclostrobin and boscalid in Botrytis cinereal isolates from strawberry fields in the Carolinas. Plant Dis. 96:1198-1203

Fisher, M. C., Henk, D. A., Briggs, C. J., Brownstein, J. S., Madoff, L. C., McCraw, S. L., and Gurr, S. J. 2012. Emerging fungal threats to 
animal, plant and ecosystem health. Nature, 484 (7393), 186- 194, DOI: $10.1038 /$ nature 10947

Fisher, N., and Meunier, B. 2008. Molecular basis of resistance to cytochrome bc1 inhibitors. FEMS Yeast Res. 8:183-192.

FRAC - Fungicide Resistance Action Committee. 2013. List of plant pathogenic organisms resistant to disease control agents. Online publication. https://www.frac.info/docs/default-source/publications/list-of-resistantplant-pathogens/list-of-resistant-plant-pathogenic-organisms---february2013.pdf?sfvrsn=4.

FRAC - Fungicide Resistance Action Committee. Introduction and general information. In Qol Fungicides. 2014. Online publication https://www.frac.info/working-group/qol-fungicides/introduction-andgeneral-information

Francl, L.J. 2001. The Disease Triangle: A plant pathological paradigm revisited. The Plant Health Instructor. DOI: 10.1094/PHI-T-2001-0517-01

Fredricks, D.N., Smith, C., and Meier, A. 2005. Comparison of six DNA extraction Methods for recovery of fungal DNA and assessed by quantitative PCR. J Clin Microbiol. 43(10):5122-5128

Gabrys, B., and Kordan, B. 2012. Cultural Control and other Non-Chemical Methods. In Insects Pests of Potato, eds. Andrei Alyokhin, Charles Vincent and Philippe Giordanengo. Pages 517-541. 
Gage, S.H., Isard, S.A., and Colunga-Garcia, M. 1999. Ecological scaling of aerobiological dispersal processes. In: Agricultural and Forest Meteorology. Vol. 97 4:149-261

Glick, B.R., and Pasternak J.J. 2003. Molecular biotechnology: Principles and Applications of recombinant DNA. $3^{\text {rd }}$ edn. American Society for Microbiology Press: Washington, DC. 759

Grau, C.G., Dorrance, A.E., Bond, J., and Russin, J.S. 2004. Fungal diseases. Pages 679-763. In: Soybean: Improvement, Production, and Uses, 3rd ed. H.R. Boerma and J.E. Specht, eds. ASA-CSSA-SSSA, Madison, WI. Hakala, K., Hannukkala, A. O., Huusela-Veistola, E., Jalli, M., and PeltonenSainio, P. 2011. Pests and diseases in a changing climate: a major challenge for Finnish crop production. Agric. Food Sci., 20, 3- 14, DOI: $10.2137 / 145960611795163042$

Haskell, R.J. 1926. Disease of cereal and forage crops in the United States in 1925. U.S. Dept. Agr. PIt. Dis. Rep. Supl. 48:375-376.]

Jackson, S.L. and Bayliss, K.L. 2011. Spore traps need improvement to fulfil plant biosecurity requirements. Plant Pathology, 60:801-810. doi:10.1111/j.1365-3059.2011.02445.x 
Kalaris, T., Fieselmann, D., Magarey, R.D., Colunga-Garcia, M., Roda, A., Hardie, D., Cogger, N., Hammond, N.E.B., Martin, P.A.T., and Whittle, P. 2014. The role of surveillance methods and technologies in plant biosecurity. In: The handbook of plant biosecurity: principles and practices for the identification, containment and control of organisms that threaten agriculture and the environment globally. Doi: 10.1007/978-94007-7365-3_11.

Koenning, S.R., and Wrather, J.A. 2010. Suppression of soybean yield potential in the continental United States by plant diseases from 2006 to 2009. Plant Health Progress 10.1094/PHP-2010-1122-01-RS.

Lacey, M.E., and West, J.S. 2006. The air spora, a manual for catching and identifying airborne biological particles. Dordrecht, the Netherlands: Springer.

Lehman, S.G. 1928. Frog-eye leaf spot of soybean caused by Cercospora diazu Miura. J. Agric. Res. 35:811-833.

Li, K., Dong, S., Wu, Y., and Yao, M. 2010. Comparison of the biological content of air samples collected at ground level and at higher elevation. Aerobiologia 26:233-244

Lin, B., and Kelly, H. 2018. Frogeye leaf spot of soybean. The Plant Health Instructor. Doi:10.1094/PHI-I-2018-1018-01.

Louws, F.J., Rademaker, J.L., and de Bruijn, F.J. 1999. The three Ds of PCRbased genomic analysis of phytobacteria: Diversity, detection, and disease diagnosis. Annu. Rev. Phytopathol. 37:81-125. 
Martin, R.R., James, D. and Lévesque, C.A. 2000. Impacts of molecular diagnostic technologies on plant disease management. Annu. Rev. Phytopathol. 38:207-239.

McCartney, H.A., Foster, S.J., Fraaije, B.A., Ward, E. 2003. Molecular diagnostics for fungal plant pathogens. Pest. Manag. Sci., 129-142. doi:10.1002/ps.575

McNew, G.L. 1960. 'The nature, origin, and evolution of parasitism' in Plant Pathology: An Advancement Treatise, Vol. 3, eds James G. Horsfall and A.E. Dimond. Academic Press, NY. Pages 19-69

Melchers, L.E. 1925. Disease of cereal and forage crops in the United States in 1924. U.S. Dept. Agr. Plt. Dis. Rep. Supl. 40:186.

Mengistu, A., Kelly, H. M., Bellaloui, N., Arelli, P.R., Reddy, K.N., and Wrather, A.J. 2014. Tillage, fungicide, and cultivar effects on frogeye leaf spot severity and yield in soybean. Plant Dis. 98:1476-1484

Mengistu, A., Kurtzweil, N.C., and Grau, C.R. 2002. First report of frogeye leaf spot (Cercospora sojina) in Wisconsin. Plant Dis. 86:1272

Mian, M.A.R., Missaoui, A.M., Walker, D.R., Phillips, D.V., and Boerma, H.R. 2008. Frogeye leaf spot of soybean: a review and proposed race designations for isolates of C. sojina Hara. Crop Sci. 48,14-24.

Mian, R., Bond. J., Joobeur, T., Mengistu, A., Wiebold, W., Shannon, G., and Wrather, A. 2009. Identification of soybean genotypes resistant to Cercospora sojina by field screening and molecular markers. Plant Disease 93:408-411 
Morton, V. and Staub, T. 2008. A Short History of Fungicides. Online publication APSnet Features. doi: 10.1094/APSnetFeature-2008-0308.

Mueller, D. S., Jeffers, S. N., and Buck, J. W. 2004. Effect of timing of fungicide applications on development of rusts on daylily, geranium, and sunflower. Plant Dis. 88:657-661.

Mueller, D.S., Wise., K.A., Dufault, N.S., Bradley, C.A., and Chilvers, M.L., eds 2013. Fungicides for field crops. APS, St. Paul, MN.

NASS Survey. Agricultural Chemical Usage. 2002. Online publication: https://quickstats.nass.usda.gov/results/C167A85B-7B95-3A57-885E734A71083DF2

NASS Survey. Agricultural Chemical Usage. 2004. Online publication: https://quickstats.nass.usda.gov/results/6F846A94-F37D-3DF3-A40F$\underline{65 F 5 A 3916 B E C}$

NASS Survey. Agricultural Chemical Usage. 2019. Online publication: https://www.nass.usda.gov/Surveys/Guide to NASS Surveys/Chemical Use/2018 Peanuts Soybeans Corn/ChemUseHighlights Soybeans 201 8.pdf

Nelson, K.A., Motavalli, P.P., Stevens, W.E., Dunn, D., and Meinhardt, C.G. 2010. Soybean response to preplant and foliar-applied potassium chloride with strobilurin fungicides. Agron. J. 102:1657-1663. 
NIH - National Human Genome Research Institute. 2020. Polymerase Chain Reaction (PCR) fact sheet. Online publication: https://www.genome.gov/about-genomics/fact-sheets/Polymerase-ChainReaction-Fact-Sheet

Pace, P.F., Weaver, D.B., and Ploper, L.D. 1993. Additional genes for resistance of frogeye leaf spot race 5 in soybean. Crop Science 33:1144-1145.

Parnell, S., Gottwald, T. R., Cunniffe, N. J., Alonso Chavez, V., \& van den Bosch, F. 2015. Early detection surveillance for an emerging plant pathogen: a rule of thumb to predict prevalence at first discovery. Proceedings. Biological sciences, 282(1814), 20151478. doi:10.1098/rspb.2015.1478 Phillips, D.V. 1999. Frogeye leaf spot. in: Compendium of Soybean Diseases, 5th ed. P 43-44. G.L. Hartman, J.C. Rupe, E.J. Sikora, L.L. Domier, J.A. Davis, and K.L. Steffey eds. American Phytopathological Society, St. Paul, MN.

Phillips, D.V., and Boerma, H.R. 1982. Two genes for resistance to race 5 of Cercospora sojina in soybean. Phytopathology 72:764-766.

Ploper, L.D., Gonzalez, V., Galvez, M.R., Devani, M.R., Ledesma, F., and Zamorano, M.A. 2001. Frogeye leaf spot of soybean caused by Cercospora sojina in northwestern Argentina. Plant Dis. 85:801.

Quesada, T., Hughes, J., Smith, K., Shin, K., James, P., and Smith, J. 2018. A low-cost spore trap allows collection and real-time PCR quantification of airborne Fusarium circinatum spores. Forests 9,586;

doi:10.3390/f9100586 
Rejmanek, M., and Pitcairn, M.J. 2003. When is eradication of exotic pest plants a realistic goal? pp. 249-253. Gland, Switzerland: IUCN-The World Conservation Union

Savage, D., Barbetti, M.J., MacLeod, W.J., Salam, M.U., and Renton, M., 2012. Mobile traps are better than stationary traps for surveillance of airborne fungal spores. Crop Protection. 36:23-30 https://doi.org/10.1016/i.cropro.2012.01.015

Scholthof, K.B.G. 2007. The disease triangle: Pathogens, the environment and society. Nature reviews. Microbiology. 5.152-6. 10.1038/nrmicro1596

Sholberg, P., O'Gordman, D., Bedford, K., Levesque, C.A. 2005. Development of a DNA microarray for detection and monitoring of economically important apple diseases, Plant dis. 89:1143-1150.

Simberloff D. 2003. How much information on population biology is needed to manage introduced species? Conserv. Biol. 17, 83-92. (10.1046/j.15231739.2003.02028.x)

Standish, J.R., Tomaso-Peterson, M., Allen, T.W., Sabanadzovic, S., and Aboughanem-Sabanadzovic, N. 2015. Occurrence of Qol fungicide resistance in Cercospora sojina from Mississippi soybean. Plant Dis. $99: 1347-1352$.

Stevens, R.B. 1960 in: Plant Pathology, and Advanced Treatise, Vol. 3, eds James G. Horsfall and A.E. Dimond Academic Press, NY. Pages 357-429. 
Strange, R. N., and Scott, P. R. 2005. Plant disease: a threat to global food security. Annu. Rev. Phytopathol, 43,83-116. Doi:

10.1146/annurev.phyto.43.113004.133839.

University of California - Davis. 2016. Why insect pests love monocultures, and how plant diversity could change that. ScienceDaily. Online publication: http:// www.sciencedaily.com/releases/2016/10/161012134054.htm

Unsworth, J. B. 2010. History of Pesticide Use. International Union of Pure and Applied Chemistry. Online Publication:

https://agrochemicals.iupac.org/index.php?option=com sobi2\&sobi2Task= sobi2Details \&catid $=3 \&$ sobi2ld $=31$

Van den Berg, F., Paveley, N. D., and Van den Bosch, F. (2016). Dose and number of applications that maximize fungicide effective life exemplified by Zymoseptoria tritici on wheat - a model analysis. Plant pathology, 65(8), 1380-1389. doi:10.1111/ppa.12558.

Van den Bosch F., Paveley, N.D., Van den Berg, F., Hobbelen, P., Oliver, R., 2014b. Mixtures as a fungicide resistance management tactic. Phytopathology 104, 1264-73.

Van den Bosch, F., Oliver, R., Van den Berg, F., Paveley, N.D., 2014a. Governing principles can guide fungicide-resistance management tactics. Annual Review of Phytopathology 52, 175-95.

Van den Bosch, F., Paveley, N.D., Shaw, M.W., Hobbelen, P.H.F., Oliver, R. 2011. The dose rate debate: does the risk of fungicide resistance increase or decrease with dose? Plant Pathology 60, 597-606. 
Vincelli, P. 2002. Qol (Strobilurin) fungicides: Benefits and Risks. The plant health instructor. doi: 10.1094/PHI-I-2002-0809-02. Updated, 2012.

Walker, J.T., Phillips, D.V., Melin, J., and Spradlin, D. 1994. Effect of intermittent acidic irrigation on soybean yields and frogeye leaf spot. Environ. Exp. Bot. 34:311-318

Ward, E., Foster, S.J., Fraaije, B.A., and McCartney, H.A. 2004. Plant pathogen diagnostics: immunological and nucleic acid-based approaches. Ann. Appl. Biol.145:1-16

Wetzel, W.C., Kharouba, H.M., Robinson, M., Holyoak, M., and Karban, R. 2016. Variability in plant nutrients reduces insect herbivore performance. Nature. $539,425-427$.

Williams, S.D., Boehm, M.J., and Mitchell, T.K. 2017. Fungal and Fungal-like Diseases of Plants. PLPATH-GEN-7 Agricultural and Natural Resources The Ohio State University. Online publication: https://ohioline.osu.edu/factsheet/plpath-gen-7

Wrather, A., Shannon, G., Balardin, R., Carregal, L., Escobar, R., Gupta, G.K., Ma, Z., Morel, W., Ploper, D., and Tenuta, A. 2010 Effect of diseases on soybean yield in the top eight producing countries in 2006. Online publication. Plant Health Prog. 10.1094/PHP-2010-0125-01-RS

Wrather, J.A., and Koenning, S.R. 2009. Effects of diseases on soybean yields in the United States 1996 to 2007. Online. Plant Health Prog. 10.1094/PHP20090401-01-RS. 
Yang, X. B., Uphoff, M.D., and Sanogo, S. 2001. Outbreaks of soybean frogeye leaf spot in lowa. Plant Dis. 85:443

Yorinori, J.T. 1992. Management of foliar fungal diseases in Brazil. Pages 185193 in: Pest Management in Soybean. L.G. Copping, M.B. Green and R.T. Rees, eds. Elsevier Applied Science, London.

Zeng, F., Arnao, E., Zhang, G., Olaya, G., Wullschleger, J., Sierotzki, H., Ming, R., Bluhm, B.H., Bond, J.P., Fakhoury, A.M., and Bradley, C.A. 2015. Characterization of quinone outside inhibitor fungicide resistance in Cercospora sojina and development of diagnostic tools for its identification. Plant Dis. 99:544-550

Zhang, G., Allen, T.W., Bond, J.P., Fakhoury, A.M., Dorrance, A.E., Weber, L., Faske, T.R., Giesler, L.J., Hershman, D.E., Kennedy, B.S., Neves, D.L., Hollier, C.A., Kelly, H.M., Newman, M.A., Kleczewski, N.M., Koenning, S.R., Thiessen, L.D., Mehl, H.L., Zhou, T., Meyer, M.D., Mueller, D.S., KandeL, Y.R., Price III, P.P., Rupe, J.C., Sikora, E.J., Standish, J.R., Tomaso-Peterson, M., Wise, K.A., and Bradley, C.A. 2018. Widespread occurrence of quinone outside inhibitor fungicide-resistant isolates of Cercospora sojina, causal agent of frogeye leaf spot of soybean, in the United States. Plant Health Prog. 19:295-302

Zhang, G., and Bradley, C.A. 2017. Comparison of quinone outside inhibitor fungicide-resistant and -sensitive isolates of Cercospora sojina. Crop Protection 94; 59-63 
Zubrod, J.P., Bundschuh, M., Arts, G., Brühl, C.A., Imfeld, G., Knäbel, A., Payraudeau,S., Rasmussen, J.J., Rohr J., Scharmüller, A., Smalling, K., Stehle, S., Schulz, R., and Schäfer, R.B. 2019. Fungicides: an overlooked pesticide class? Environ. Sci. Technol. (53) 7:3347-3365. 
CHAPTER 2: Survey of Missouri fields for azoxystrobin resistant

\section{Cercospora sojina Isolates}

Average yield losses attributed to soybean diseases surpass $\$ 4.5$ billion annually, which accounts for $11 \%$ of the total soybean production in the U.S. (Bandara et al. 2020). Disease causing pathogens that are responsible for the astonishing high profit losses affect host plants by both the disruption of regular response processes and reducing the ability of the host plant to properly thrive (Mandadi and Scholthof 2013). Proper identification of plant pathogens is one of the most important pieces of successful disease management programs. Misidentification of disease-causing agents can be detrimental to production through increasing yield loss and input costs, as well as contributing to fungicide resistance development.

Frogeye leaf spot (FLS), caused by the fungus Cercospora sojina, is a foliar disease responsible for an average of 15 bu/acre in soybean yield losses annually in the U.S. and Canada (Allen et al. 2017). FLS also can affect other parts of the soybean plant, such as pods, stems and seeds increasing the potential for yield loss (Westphal et al. 2006; Boyer et al. 2017). With yield losses reaching up to $60 \%$ in severe cases, FLS has been a problem for soybean producers in the U.S for decades (Laviolette et al. 1970; Dashiell and Akem 1991; Akem and Dashiell 1994; Ma 1994; Mian et al. 1998; Mengistu et al. 2014, Boyer et al. 2017). Along with planting FLS resistant cultivars (Mian et al. 1998; Boyer et al. 2017), crop rotation (Mwase and Kapooria 2001; Boyer et al. 2017) and utilizing fungicide treated seeds (Poag et al. 2005; Boyer et al. 2017), foliar 
fungicide applications can help reduce FLS disease levels, yet they do not eliminate nor reduce existing infections (Boyer et al. 2017). Fungicide applications for FLS are designed to protect new growth from being infected by the fungus (Dashiell and Akem 1991; Akem and Dashiell 1994; Boyer et al. 2017).

The genus Cercospora Fresen. contains two soybean-specific pathogens: C. sojina Hara and C. kikuchii (Hartman et al. 1999; Soares et al. 2015). The latter pathogen is responsible for Cercospora leaf blight (CLB) and purple stain seed (PSS) (Matsumoto and Tomoyasu 1925; Walters 1980; Soares et al. 2015). Management of these two soybean diseases has relied on broad spectrum benzimidazole or strobilurin fungicide applications, either alone or in combination (Dorrance et al. 2007; Soares et al. 2015). The fungus C. sojina can be found in most major soybean producing areas in the world (Athow and Probst 1952; Bernaux 1979; Akem et al. 1992; Ma 1994; Mian et al. 2008). Under the right environmental conditions, this pathogen quickly produces a large quantity of spores which can be the reason for its broad genetic diversity and widespread virulence (Mian et al. 2008). Cercospora sojina has biological characteristics that make it prone to fungicide resistance development.

Qol resistant C. sojina was first detected in Tennessee in 2010 (Zhang et al. 2012). The development of fungicide resistance in $C$. sojina is of the qualitative type which is often referred to as an on/off switch as resistance phenotypes produce discrete classes of resistant and susceptible isolates (Corwin and Kiebenstein 2017). Qol fungicides are designed to inhibit 
mitochondrial respiration by blocking electron transfer between cytochrome $b$ and cytochrome c1 (Bartlett et al. 2002; Zeng et al. 2015). Isolates of $C$. sojina can have one of three point mutations in its genome on cytochrome $b$ to bypass the inhibition of mitochondrial respiration resulting in resistance to the Qol class of fungicides: codon 143 (G143A), codon 129 (F129L), or codon 137 (G137R) (Zeng et al. 2015). Each mutation differs in their effect on resistance to Qol fungicides, but the most common mutation is G143A (Zeng et al. 2015). The G143A mutation is also the point mutation with the highest level of occurrence (Fisher and Meunier 2008; Zeng et al. 2015).

After Qol resistant $C$. Sojina was first detected in Tennessee, a collection of $C$. Sojina isolates in the region were surveyed for further presence of fungicide resistance (Zhang et al. 2018). By 2017, fungicide resistance had been detected in 14 states with additional states and counties noting new presence of Qol resistant $C$. Sojina annually (Zhang et al. 2018). The newest states with detected resistance include Nebraska in 2019 (Jackson-Ziems 2020; Neves et al. 2020) and lowa in 2017 (Mueller et al. 2018).

Given the current distribution of fungicide resistant $C$. sojina isolates in the states surrounding Missouri (Zhang et al. 2018), this study's main objective was to assess the current distribution of $C$. sojina fungicide resistant isolates in the state of Missouri. This was completed through conducting a i) fungicide sensitivity bioassay, ii) conidial germination test, and iii) by using DNA analysis to confirm pathogen identification and Qol fungicide resistance. 


\subsection{Materials and Methods}

i. Field Collection

Soybean leaf samples exhibiting FLS symptoms were collected between May of 2019 and September of 2020 from soybean fields in 15 Missouri counties (Figure 2.1). A total of 11 fields were sampled in 2019 and 11 fields in 2020 (Table 2.1). Fields were initially selected based on their proximity to fields with a history of FLS, and field selections finalized by the presence of FLS symptoms at the time of sampling. At each of the locations, at least ten soybean leaves with FLS lesions were collected from fields using a W or M scouting pattern and the leaves placed in plastic or paper bags for transport to the laboratory. Some samples were collected by collaborators; these samples were refrigerated at $4^{\circ} \mathrm{C}$ until they could be transported to the Columbia campus.

ii. Isolate Recovery

Leaves with pathogen present had lesions observed under a light microscope to verify if present spore's morphology matched $C$. sojina's ascospore morphology (Phillips 1999). Hyaline conidia, both the primary and secondary inoculum of $C$. sojina, are cylindrical to fusiform and measure 5 to $7 \mu \mathrm{m} \times 39$ to $70 \mu \mathrm{m}$ (Lin and Kelly 2018). Samples matching this characteristic were used for further isolation.

Putative $C$. sojina isolates were recovered from leaf samples by gently rubbing the surface of a lesion with a sterile toothpick and placing the spores into a $60 \mathrm{~mm}$ by $15 \mathrm{~mm}$ petri dish (Fisher Scientific, Waltham, MA) containing full strength potato dextrose agar (PDA; 39g of PDA/L) amended with rifampicin 
(25mg/L). All lesions from each field location were sampled in this manner. After 24 hours, six germinated single spores from were collected from individual plates (one germinated spore per plate) and transferred to separate $60 \mathrm{~mm}$ by $15 \mathrm{~mm}$ petri dishes (Fisher Scientific, Waltham, MA) containing soybean stem lima-bean agar (SSLB) (Phillips and Boerma 1981). The SSLB plates containing single spores were placed on a fluorescent light cart for growth under a 12-hour day/night cycle at $25^{\circ} \mathrm{C}$ until approximately $80 \%$ of the surface of the plate was covered.

Each isolate that was grown on an SSLB plate was subsequently subcultured onto four full strength PDA plates with rifampicin. Two plates were reserved for long term storage according to Zhang et al. (2012), one pure culture plate was used for the poison plate assay, and one plate was used for isolation of DNA.

iii. Fungicide Sensitivity Bioassay

A fungicide sensitivity bioassay was conducted to test the fungicide resistance of $C$. sojina isolates to the Qol class of fungicides by using technicalgrade azoxystrobin (96\% a.i.; Syngenta Crop Protection, Greensboro, NC). To create a $100 \mathrm{ppm}$ stock solution, $0.104 \mathrm{~g}$ of technical-grade azoxystrobin was diluted in $1 \mathrm{~mL}$ of acetone. To reach all five desired concentrations to conduct the sensitivity assay (0.1 ppm, 1 ppm, 5 ppm, 10 ppm, 15 ppm), dilutions were prepared by mixing 1 part stock solution and 9 parts acetone. Salicylhydroxamic acid (SHAM) was added to all concentrations and a control mixture of acetone to ensure conidia would not germinate via an alternate pathway (Wood and 
Hollomon, 2003). SHAM was dissolved in methanol and added to all treatments at a final concentration of $60 \mathrm{ppm}$. To prepare the PDA plates, $5.85 \mathrm{~g}$ of PDA was added to $150 \mathrm{~mL}$ of deionized water and the solution autoclaved. The sterile PDA solution was allowed to cool, then $150 \mu \mathrm{L}$ each of the azoxystrobin concentrations were added, along with SHAM to a final concentration of $60 \mathrm{ppm}$. The control plates contained $150 \mu \mathrm{L}$ of acetone (no azoxystrobin added), 60ppm of SHAM and 90ppm of methanol. After all chemicals were added, the PDA solutions were thoroughly mixed and poured into $60 \mathrm{~mm} \times 10 \mathrm{~mm}$ petri plates.

A plug of approximately $5 \mathrm{~mm} \times 5 \mathrm{~mm}$ from each pure isolate was placed in the center of each plate of the fungicide dilution series. Each series was replicated four times. Plates were then placed on a light cart under a 12-hour day/night regimen at room temperature $\left(25^{\circ} \mathrm{C}\right)$ for three weeks. At the end of the three-week period, each plate was scanned using an Epson Perfection V600 photo flatbed scanner (Epson; Long Beach, CA). Each image consisted of six plates, one from each fungicide concentration $(0.1 \mathrm{ppm} ; 1 \mathrm{ppm} ; 5 \mathrm{ppm} ; 10 \mathrm{ppm}$; 15ppm; and control). After scanning, image files were edited using paint 3D (Microsoft company; Redmont, WA) to fit each plate as a 550-pixel by 550-pixel square for standardization and analysis with MatLab software (MathWorks; Natick, MA) to measure the area of mycelium on each plate. Due to the uneven growth pattern of $C$. sojina isolates, the use of MatLab allowed for a more accurate assessment of the mycelial growth area on the plate. For each isolate, average growth was calculated. 
An isolate was considered resistant to azoxystrobin when size of the mycelium was greater than or equal to $5 \%$, as the $5 \mathrm{~mm} \times 5 \mathrm{~mm}$ pure culture plug accounted for $5 \%$ of the area of the $60 \mathrm{~mm} \times 10 \mathrm{~mm}$ plate. Each isolate tested as Qol-resistant in the fungicide sensitivity bioassay was submitted to sporulation and radial growth tests following the protocol of Zhang and Bradley (2017). In preparation for these tests, spores were collected by adding $15 \mu \mathrm{L}$ of sterile water to the mycelium of a pure culture plate and recovering the same volume of water from the plate via pipet. The $15 \mu \mathrm{L}$ droplet containing spores was then spread onto a new petri dish containing full strength PDA. After 24-36 hours, six germinating single spores were placed on six SSLB petri plates. After five days of growth, the spores were extracted from three of the plates and added to $500 \mu \mathrm{L}$ of sterile water for the sporulation test (Zhang and Bradley 2017). Spore counts were determined using a hemocytometer and counting the number of spores in $10 \mu \mathrm{L}$ of the solution. The other three plates were used for fungi growth test and were left to grow for 12 days. To evaluate growth of the fungal colonies, plates were scanned using an Epson perfection V600 photo flatbed scanner on days 6 and 12.

iv. Identification of $C$. sojina Fungicide Resistance Through PCR

Cercospora sojina mycelium was transferred with a sterile cell scraper into a $2 \mathrm{~mL}$ Eppendorf tube, and fungal DNA was extracted using DNeasy plant mini kits (Qiagen, Hilden - Germany) according to manufacturer's instructions. A PCR test was conducted using oligonucleotide primers developed by Zeng et al. (2015) to distinguish wild type C. sojina from mutant Qol-resistant C. sojina 
(Table 2.2). PCR primers were synthesized by Integrated DNA Technologies (Coralville, lowa). PCR tests were conducted using a 6325 Mastercycler Pro thermal cycler (Eppendorf, Hamburg, Germany) in $50 \mu \mathrm{L}$ reaction volumes. Each well contained $10 \mu \mathrm{L}$ of Green GoTaq Flexi Buffer, $1 \mu \mathrm{L}$ of GoTaq Hot Start Polymerase $(5 \mathrm{u} / \mu \mathrm{l}), 1 \mu \mathrm{L}$ of nucleotide mix, and $2 \mu \mathrm{L}$ of $\mathrm{MgCl}_{2}$ (all supplied by Promega Corp., Madison, $\mathrm{WI}$ ), $2 \mu \mathrm{L}$ of forward and $2 \mu \mathrm{L}$ of reverse primers (100 $\mu \mathrm{M}$ solution), $1 \mu \mathrm{L}$ of the DNA template and $31 \mu \mathrm{L}$ of deionized water bringing the total volume of each reaction mixture to $50 \mu \mathrm{L}$. Thermal cycler conditions were set according to Zeng et al. (2015): DNA was denatured at $95^{\circ} \mathrm{C}$ for 2 minutes, amplified for 30 cycles with a denaturation phase of $95^{\circ} \mathrm{C}$ for 30 seconds, annealing at $50^{\circ} \mathrm{C}$ for 30 seconds, and extension at $72^{\circ} \mathrm{C}$ for 1 minute. The final extension lasted 5 min at $72^{\circ} \mathrm{C}$ to complete the PCR reaction.

\subsection{Results}

i. Isolate Recovery

During the 2 years of this study, 121 isolates representing 15 Missouri counties were collected. In all, 82 isolates grew across all five fungicide concentrations and growth was inhibited in all five fungicide concentrations for 39 isolates. Of the 15 surveyed counties, four were in the northwest region, one in the southwest region, two in the northeast region, two in the southeast region, and six in the central portion of the state. The largest percentage of sensitive isolates were recovered in the central portion of the state (53.65\%) (Table 2.3). 
The four northwest counties accounted for most fungicide resistant isolates recovered, 49 samples (Table 2.3), and the second lowest percentage $(22.23 \%)$ of sensitive isolates in the state.

Between the years of 2019 and 2020, the number of resistant isolates collected in Missouri rose from 32 to 50 while the number of sensitive isolates dropped from 23 to 16 (Table 2.1). In a two year period, there was an increase of over $56 \%$ in collection of fungicide resistant isolates and a decrease of more than $30 \%$ in the recovery of Qol sensitive isolates.

The 82 isolates found to be Qol resistant in the fungicide sensitivity bioassay were used in a subsequent spore viability test to ensure spores had potential for field reproduction. All 82 azoxystrobin fungicide resistant isolates were able to reproduce and produce viable spores after the completion of the sporulation test.

ii. DNA Identification of G143A Mutation C. sojina

The 82 isolates which tested as azoxystrobin-resistant in the fungicide sensitivity assay also were tested for the G143A mutation via PCR. Of the 82 isolates analyzed by the University of Missouri DNA Core Facility using DNA sequencing Sanger, utilizing 3730xl 96-capillary DNA Analyzer with Applied Biosystems Big Dye Terminator cycle sequencing chemistry, 45 were confirmed to have the G143A mutation (Table 2.4). When separated by region, 30 were in the northwest region, 1 in southwest, 4 in southeast, 6 in northeast, and 8 in the central region. In total, the G143A mutation accounted for $59.76 \%$ of the Qol resistant isolates recovered in this survey. Interesting enough, 4 resistant 
samples had an unknown type of resistance, meaning they could have been affected by one of the other two types of mutation (F129L or G137R) resulting in Qol resistance in C. sojina to be resistant. After receiving the DNA sequencing analysis provided by the University of Missouri DNA Core Facility, it was identified that 25 samples that were resistant to Qol fungicides in the fungicide sensitivity assay did not contain a fungicide mutation and were of the wild type.

\subsection{Discussion}

The purpose of this study was to assess the current distribution of fungicide resistant Cercospora sojina isolates in Missouri. Fungicide resistant $C$. sojina was first reported in Missouri in 2011 and 2012 (Zhang and Bradley 2017); however, no formal assessment of $\mathrm{Qol}$ resistant $C$. sojina isolates has been conducted in the state to date. As a result, local farmers were not aware of the distribution of fungicide resistance in the FLS pathogen in Missouri. Results of this study indicate that resistance to the fungicide azoxystrobin in $C$. sojina is present in an additional 14 counties in addition to the two originally identified counties in Missouri in 2011 and 2012.

In 2019 and 2020, the incidence of FLS was very low in many areas of Missouri primarily due to environmental conditions. Comparing the weather data generated by the Midwestern Regional Climate Center for both precipitation and temperature for the years of 2019 and 2020, it is possible to see how temperature and precipitation may have had a direct impact on the presence of FLS within the state. As depicted in Figure 2.2 and Figure 2.3, the month of June 2019 started out wetter than normal in most of the state but in July 2019, the 
central and northern portions of Missouri were about 1 to 3 inches below average in total rainfall. By August 2019, the northern portion of the state remained dry, but was not in a severe drought. On average, the summer of 2019 in northern Missouri had less than normal rainfall and it also had slightly warmer temperatures. The temperature and precipitation combination made it so that the overall conditions were not favorable for FLS development in that region due to the lack of precipitation. The central and southern portions of Missouri had temperatures that were average to below average for the 1981-2010 normals, the two portions also three to nine inches of above average precipitation for the June to August period.

In 2020, the scenario was different. Figures 2.4 and 2.5 depict a warmer and drier than average summer season. As soybean growth progressed into the reproductive stages around the period of time that $C$. sojina infection would be expected to begin, conditions were favorable in the northwest portion of the state and in isolated locations in the central portion of the state. Cooler, dry conditions in the southwest and south-central portion of the state could explain the low levels of FLS reported in these areas in 2020.

Even though FLS presence was low during the 2 years of the study, 121 isolates from 15 counties were collected. Fungicide-resistant isolates accounted for $67.76 \%$ of the total number of isolates, of those $59.76 \%$ containing the G143A mutation, indicating that a mixture of both sensitive and resistant isolates are still present in Missouri. This differs from the findings of Mengistu et al. (2019) where it was found that $88 \%$ of the isolates collected from 11 states within the U.S. and 
two countries were sensitive to the azoxystrobin fungicide. The results here found are similar to Neves et al. (2020) in which $93.25 \%$ of the isolates collected in Michigan, Minnesota and Nebraska tested positive to Qol resistance. As the recovery rate of sensitive isolates in Missouri surpasses 30\%, it is possible that populations of $C$. sojina are still susceptible to the Qol fungicide in the state. These results confirm the widespread nature of azoxystrobin resistance in $C$. sojina populations also demonstrated in studies from states in the central and southern U.S. (Standish et al. 2015; Zhang et al. 2018).

When thinking about the widespread distribution of FLS and how Qol resistance is being found in more counties and states each year, it is important to look back at the Zhang et al. (2018) compilation of counties and parishes that have had Qol resistance confirmed. In this study, when the isolates were grouped by region of the state, it was apparent that higher levels of $C$. sojina recovery and fungicide resistant isolates are present in the northwest portion of the state. Fungicide resistant isolates of $C$. sojina were recently identified in Nebraska (Neves et al. 2020) and lowa (Zhang et al. 2018). Markell et al. (2020) also reports the first report of FLS in North Dakota, indicating that $C$. sojina and potential fungicide resistance is continuing to move into new areas of the country. By continuing to survey areas that have not had FLS present and tracking resistance development into new and previously undetected locations, efforts to improve integrated pest management strategies tailored to Qol resistant pathogens can be developed based on the region it is present at. 
The findings presented here indicate that $C$. sojina isolates resistant to the azoxystrobin fungicide are more widespread in Missouri than previously thought. The data collected from the Missouri fields resulted in more accurate visualization of where resistant and sensitive isolates are located as well as help identifying areas that were under sampled and need to be more properly scouted for a better representation. Future research into the impacts of double cropping on fungicide use and resistance, genetic similarities in fungicide-resistant $C$. sojina populations, and how other pathogens interfere with Qol resistant isolates is necessary to better understand the impacts of $C$. sojina on soybean production. 


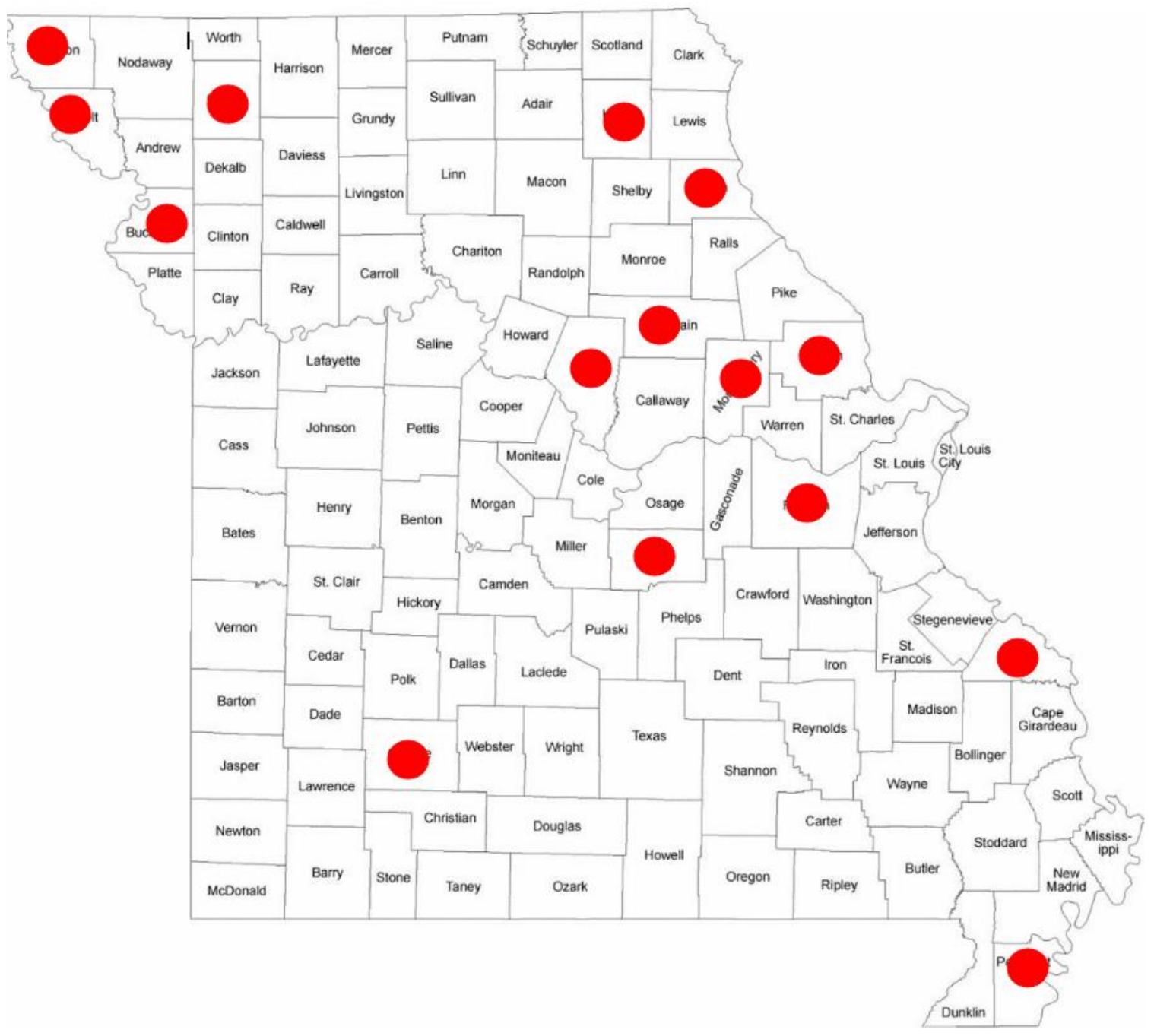

Figure 2.1. Counties where Cercospora sojina isolates were collected in Missouri during the 2019 and 2020 growing seasons. 


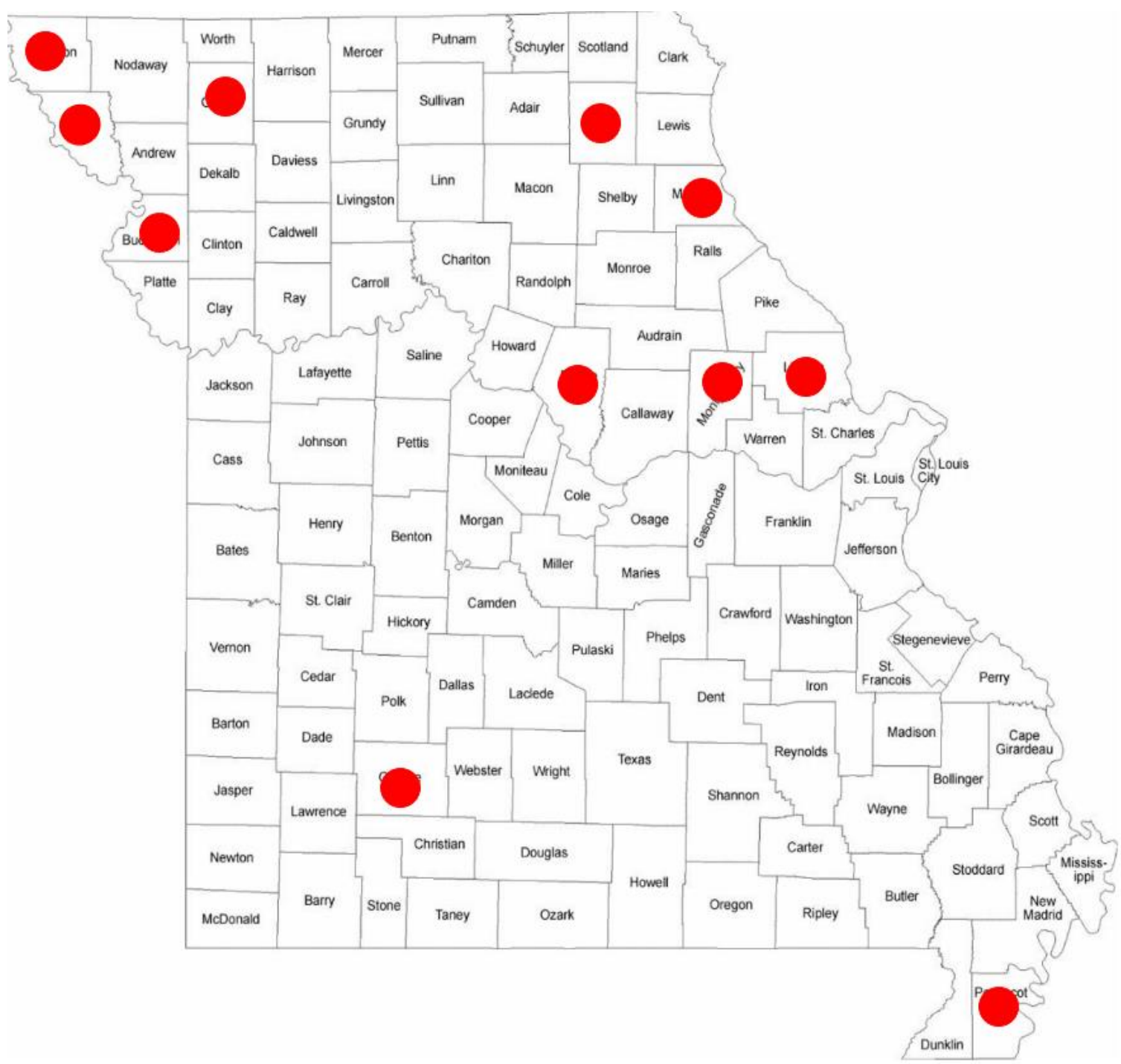

Figure 2.2. List of counties where Qol fungicide-resistant Cercospora sojina isolates were confirmed in Missouri during the 2019-2020 growing seasons. 


\begin{tabular}{|c|c|c|c|c|c|c|}
\hline & & 2019 & ISOLATES & & 2020 & ISOLATES \\
\hline COUNTY & $\begin{array}{c}\text { \# OF } \\
\text { FIELDS }\end{array}$ & RESISTANT & SENSITIVE & $\begin{array}{c}\text { \# OF } \\
\text { FIELDS }\end{array}$ & RESISTANT & SENSITIVE \\
\hline Audrain & 2 & 2 & 4 & - & - & - \\
\hline Atchison & 1 & 7 & 3 & 3 & 21 & 0 \\
\hline Boone & 1 & 1 & 4 & 1 & 2 & 5 \\
\hline Buchanan & - & - & - & 1 & 1 & 0 \\
\hline Franklin & - & - & - & 1 & 5 & 2 \\
\hline Gentry & 1 & 8 & 7 & - & - & - \\
\hline Greene & 1 & 1 & 2 & - & - & - \\
\hline Holt & - & - & - & 3 & 12 & 4 \\
\hline Knox & 1 & 5 & 0 & - & - & - \\
\hline Lincoln & - & - & - & 1 & 7 & 0 \\
\hline Maries & 1 & 0 & 2 & - & - & - \\
\hline Marion & 1 & 3 & 0 & - & - & - \\
\hline Montgomery & - & - & - & 1 & 2 & 5 \\
\hline Pemiscot & 1 & 5 & 0 & - & - & - \\
\hline Perry & 1 & 0 & 1 & - & - & - \\
\hline TOTAL & 11 & 32 & 23 & 11 & 50 & 16 \\
\hline
\end{tabular}

Table 2.1. Quantity of Cercospora sojina isolates collected during the years of 2019 and 2020 classified as resistant or sensitive to the Qol class of fungicides via fungicide sensitivity assay. An isolate was said to be fungicide resistant when growth was present in all 5 ranges of fungicide-amended PDA plates. 


\begin{tabular}{|c|c|c|c|c|}
\hline Name & Direction & $\begin{array}{l}\text { Product size } \\
\text { (bp) }\end{array}$ & Sequence $\left(5^{\prime}-3^{\prime}\right)$ & $\begin{array}{c}\text { Other } \\
\text { information }\end{array}$ \\
\hline Cs-1F & Forward & \multirow{2}{*}{207} & TAATACAGCTTCAGCATTTTTCTTCT & \multirow{2}{*}{$\begin{array}{c}\text { G143A-specific } \\
\text { primer } \\
\text { (optimized) }\end{array}$} \\
\hline Cs-1R-2 & Reverse & & CTCATTAAATTAGTAATAACTGTGGCCG & \\
\hline Cs-2F & Forward & \multirow{2}{*}{359} & GGTTCACTATTAGGATTTTTGTCTTGTA & \multirow{2}{*}{$\begin{array}{c}\text { Wild Type- } \\
\text { specific primer } \\
\text { (optimized) }\end{array}$} \\
\hline Cs-5R-2 & Reverse & & CTCATTAAATTAGTAATAACTGTGGCCC & \\
\hline
\end{tabular}

Table 2.2. Primers utilized for PCR to confirm the presence of Qol resistance in Cercospora sojina. Sets were selected based on primers developed by Zheng et al. (2015) which represented both the wild type and the G143A point mutation present in the mutant of the most common resistance gene in C. sojina. 


\begin{tabular}{|c|c|c|c|c|}
\hline STATE AREA & \# OF COUNTIES & \# OF SAMPLES & $\begin{array}{c}\text { \% OF SENSITIVE } \\
\text { SAMPLES }\end{array}$ & $\begin{array}{c}\text { \% OF RESISTANT } \\
\text { SAMPLES }\end{array}$ \\
\hline Northwest & 4 & 63 & 22.23 & 77.78 \\
\hline Southwest & 1 & 3 & 33.33 & 66.67 \\
\hline Northeast & 2 & 8 & 0 & 100 \\
\hline Southeast & 2 & 6 & 16.66 & 83.34 \\
\hline Central & 6 & 41 & 53.65 & 46.35 \\
\hline
\end{tabular}

Table 2.3. Percentage of Qol fungicide resistant and sensitive Cercospora sojina isolates collected by area of the state of Missouri between 2019 and 2020. 


\begin{tabular}{|c|c|c|c|}
\hline AREA OF MISSOURI & $\begin{array}{c}\text { \# OF SAMPLES OF } \\
\text { WITH WILD TYPE }\end{array}$ & $\begin{array}{c}\text { \# OF SAMPLES WITH } \\
\text { G143A MUTATION }\end{array}$ & $\begin{array}{c}\text { \# OF SAMPLES WITH } \\
\text { UNKNOWN MUTATION }\end{array}$ \\
\hline NORTHWEST & 8 & 40 & 1 \\
\hline SOUTHWEST & - & 1 & - \\
\hline NORTHEAST & 2 & 6 & 1 \\
\hline SOUTHEAST & - & 4 & 2 \\
\hline CENTRAL & 5 & 8 & \\
\hline
\end{tabular}

Table 2.4. DNA Sanger sequencing analysis by the University of Missouri DNA Core Facility of 84 Cercospora sojina isolates which exhibited fungicide resistance in the fungicide sensitivity assay. Primers for the wild type and G143A mutation were derived from Zheng et al. (2015). Isolates are divided into those with the wildtype sequence present, those that contained the G143A mutation, and those with an unknown mutation by area (Northwest, Southwest, Northeast, Southeast, and Central) of Missouri. 
Average Temperature $\left({ }^{\circ} \mathrm{F}\right)$ : Departure from 1981-2010 Normals

June 01, 2019 to June 30, 2019
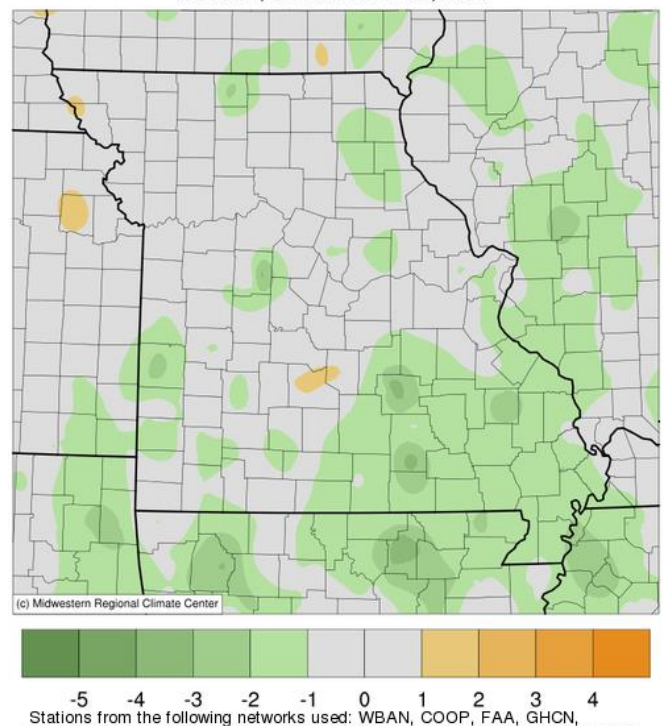

ThreadEx, CoCORaHS, WMO, ICAO, NWSH, Missouri FSA, Missouri Mesonet,

Midwestern Regional Climate Center
cli-MATE: MRCC Application Tools Environment

Average Temperature ( $\left.{ }^{\circ} \mathrm{F}\right)$ : Departure from 1981-2010 Normals August 01, 2019 to August 31, 2019
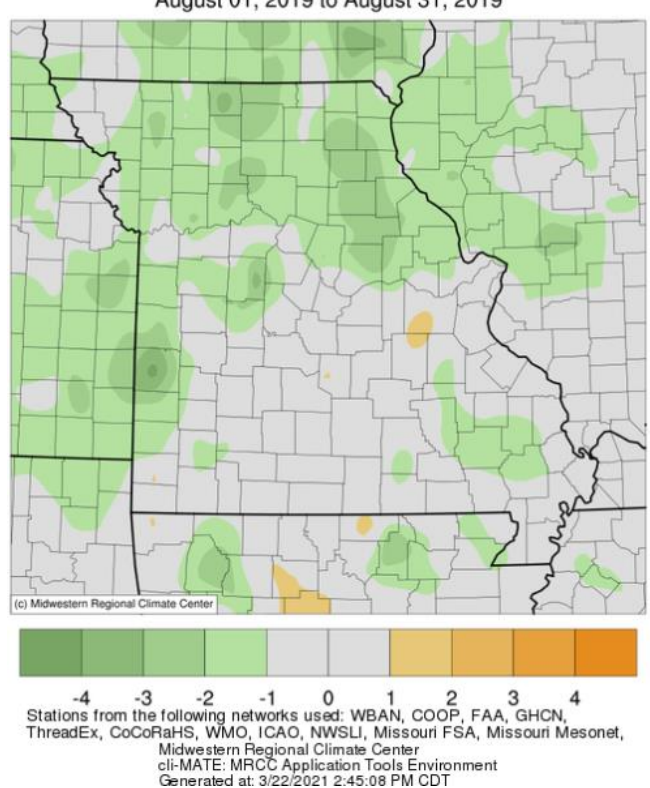

Average Temperature $\left({ }^{\circ} \mathrm{F}\right)$ : Departure from 1981-2010 Normals July 01,2019 to July 31,2019
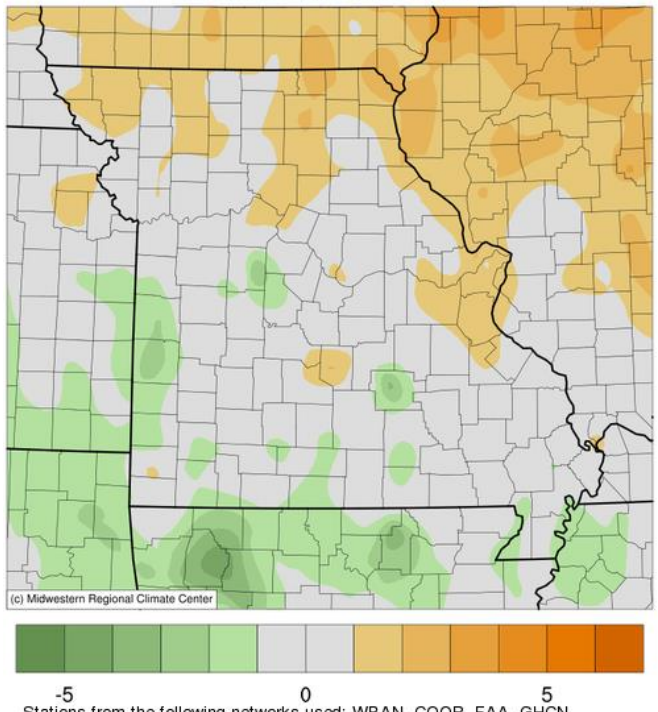

ThreadEx, COCORAHS, WMO, ICAO, NWSLI, Missouri FSA, Missouri Mesonet, Midwestern Regional Climate Center
cli-MATE: MRCC Application Tools Environment

Average Temperature $\left({ }^{\circ} \mathrm{F}\right)$ : Departure from 1981-2010 Normals June 01, 2019 to August 31, 2019

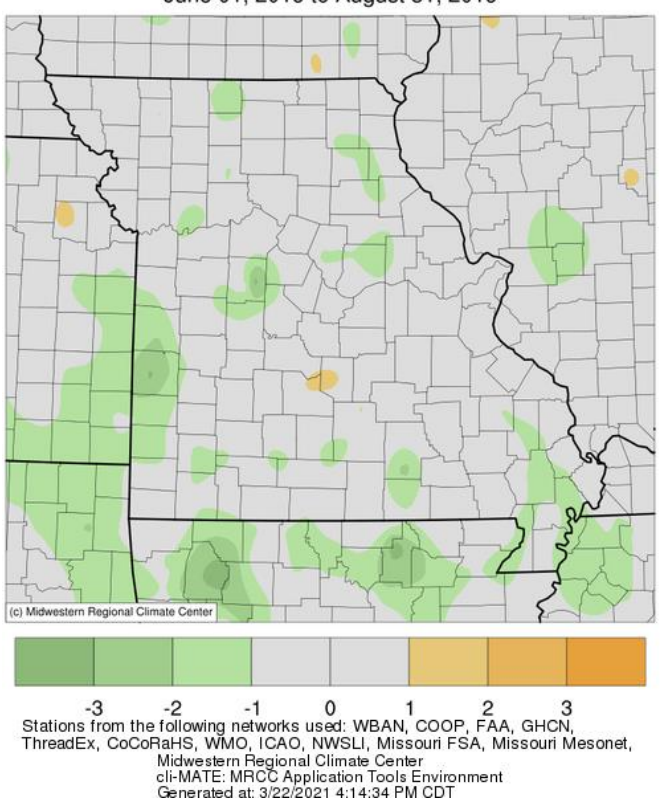

Figure 2.3. Average temperature in Missouri between June $1^{\text {st }}, 2019$ to

August $31^{\text {st }}, 2019$ and how it differs from the 1981-2010 normal average. Online publication by Midwestern Regional Climate Center (MRCC

https://mrcc.illinois.edu 2021). 
Accumulated Precipitation (in): Departure from 1981-2010 Normals Accumulated Precipitation (in): Departure from 1981-2010 Normals June 01, 2019 to June 30, 2019

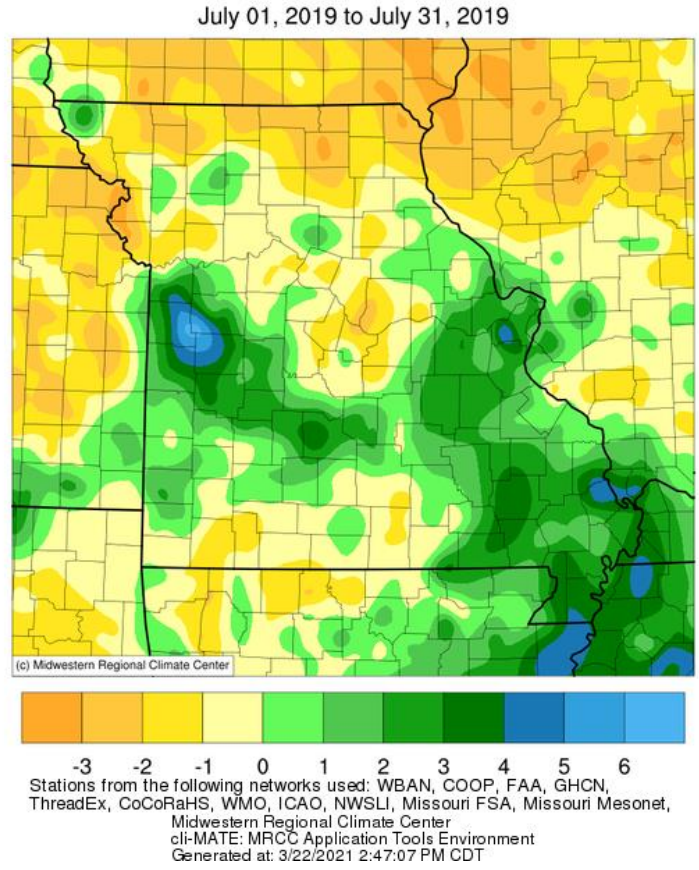

Accumulated Precipitation (in): Departure from 1981-2010 Normals August 01, 2019 to August 31, 2019

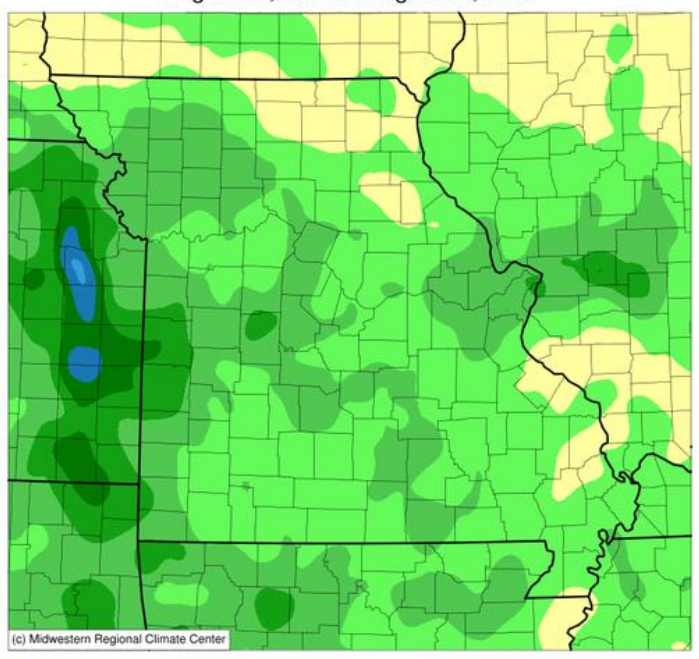

Accumulated Precipitation (in): Departure from 1981-2010 Normals June 01, 2019 to August 31, 2019

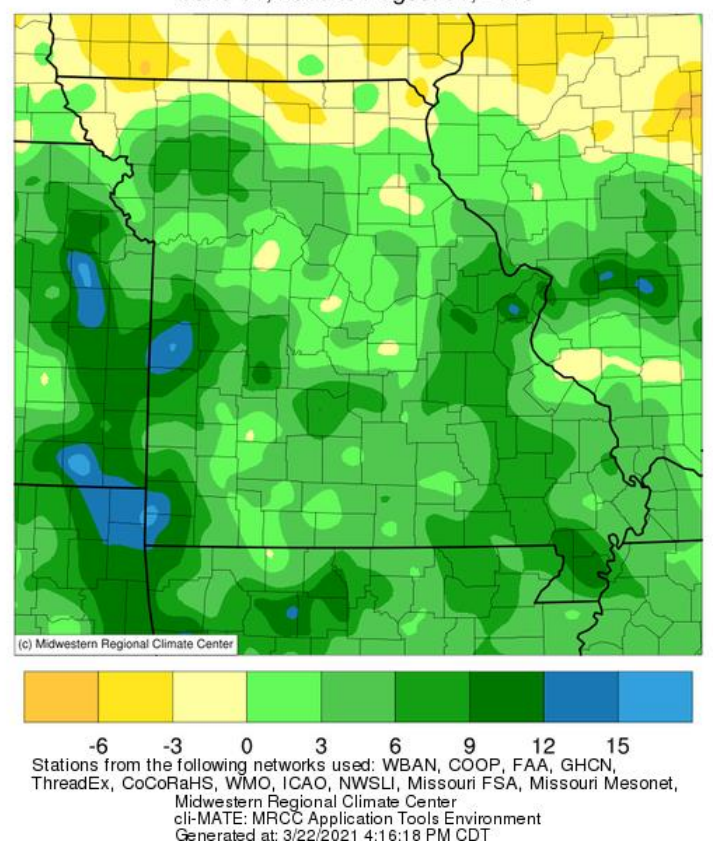

Figure 2.4. Average precipitation, shown in inches, in Missouri between

June $1^{\text {st }}, 2019$ to August $31^{\text {st }}, 2019$ and how it differs from the $1981-2010$ normal average. Online publication by Midwestern Regional Climate Center (MRCC https://mrcc.illinois.edu 2021). 
Average Temperature $\left({ }^{\circ} \mathrm{F}\right)$ : Departure from 1981-2010 Normals June 01,2020 to June 30,2020
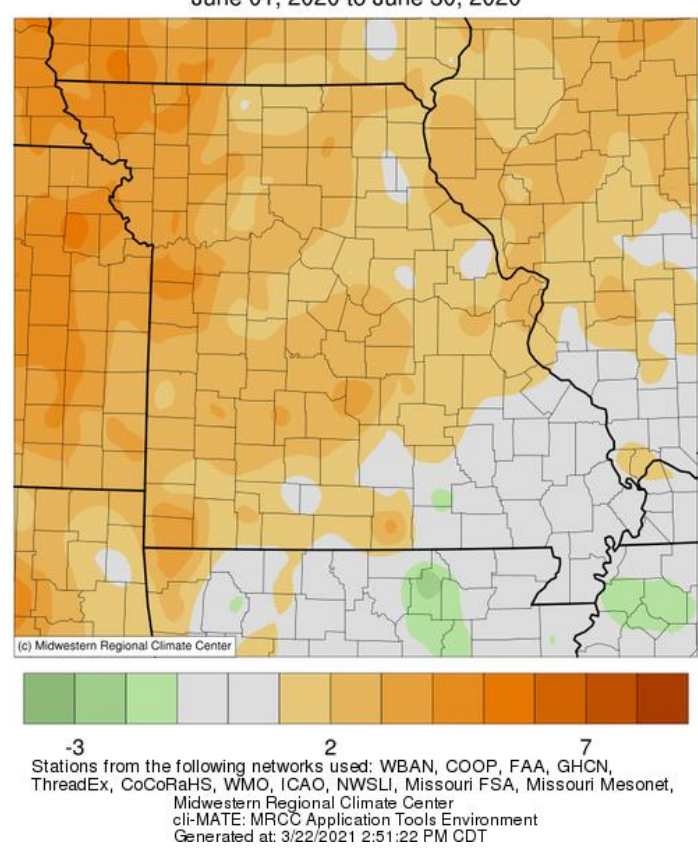

Average Temperature $\left({ }^{\circ} \mathrm{F}\right)$ : Departure from 1981-2010 Normals August 01,2020 to August 31,2020
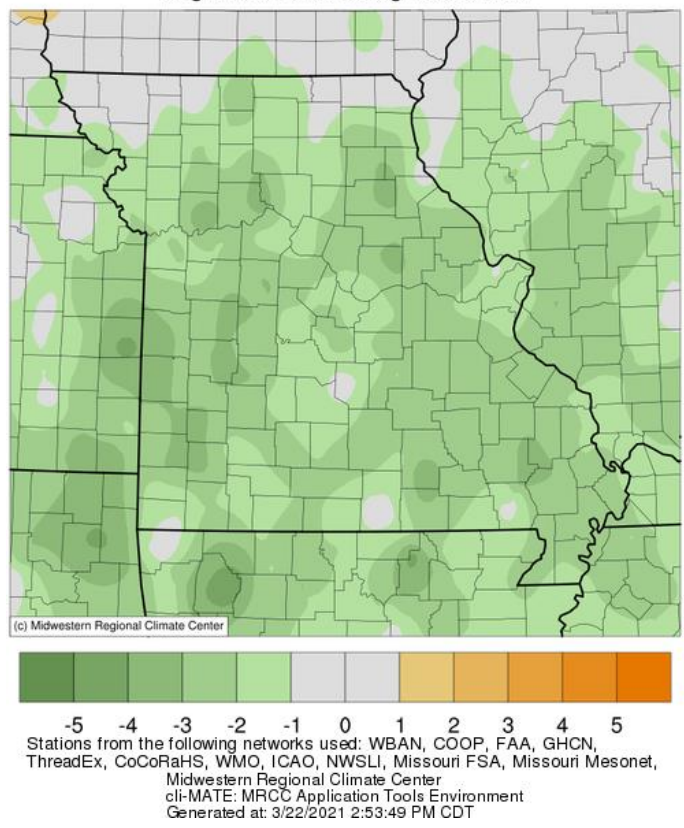

Average Temperature $\left({ }^{\circ} \mathrm{F}\right)$ : Departure from 1981-2010 Normals July 01,2020 to July 31,2020
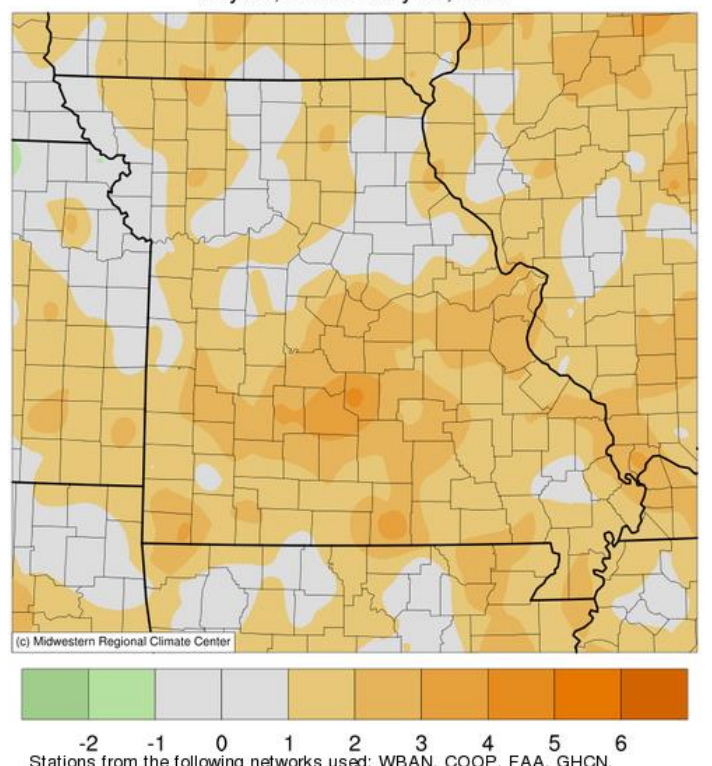

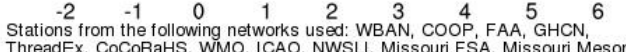
Midwestern Regional Climate Center
cli-MATE: MRCCC Application Tools Environment
Generated at $3 / 22 / 20212: 52: 44$ PM CDT

Average Temperature $\left({ }^{\circ} \mathrm{F}\right)$ : Departure from 1981-2010 Normals June 01, 2020 to August 31, 2020
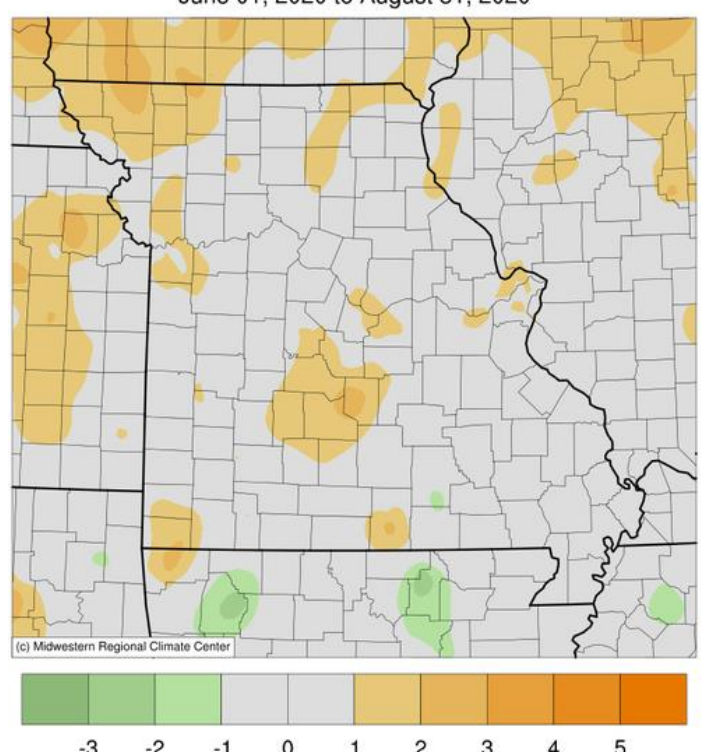

$\begin{array}{ccccccc}-3 & -2 & -1 & 0 & 1 & 2 & 3 \\ \text { Stations from the following networks used: WBAN, COOP, FAA, GHCN, } & 4\end{array}$ ThreadEx, CoCoRaHS, WMO, ICAO, NWSLI, Missouri FSA, Missouri Mesonet, Midwestern Regional Climate Center cli-MATE: MRCC Application Tools Environment

Figure 2.5. Average temperature, shown in Fahrenheit, in Missouri between June $1^{\text {st }}, 2020$ to August $31^{\text {st }}, 2020$ and how it differs from the 19812010 normal average. Online publication by Midwestern Regional Climate Center (MRCC https://mrcc.illinois.edu 2021). 
Accumulated Precipitation (in): Departure from 1981-2010 Normals June 01, 2020 to June 30,2020
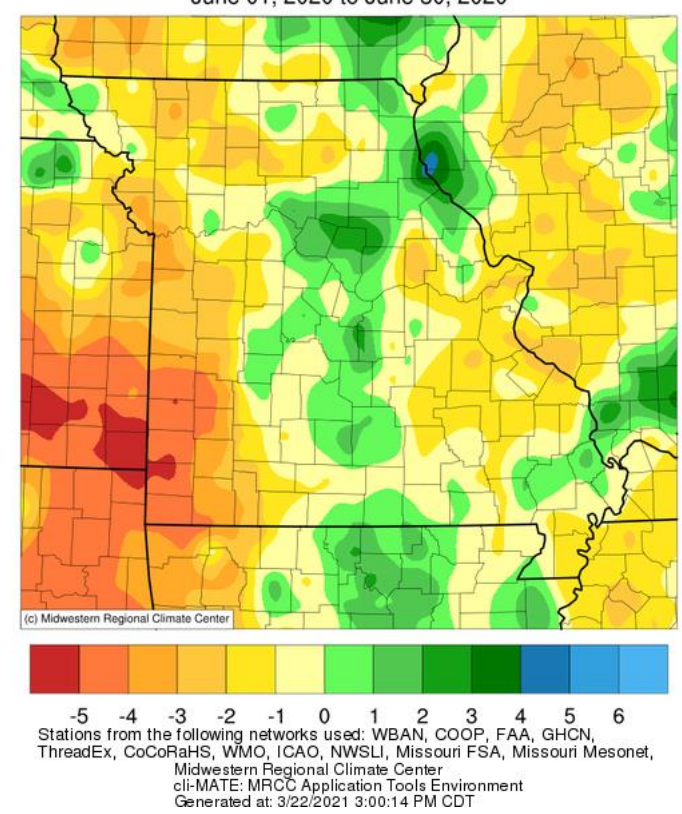

Accumulated Precipitation (in): Departure from 1981-2010 Normals August 01,2020 to August 31, 2020

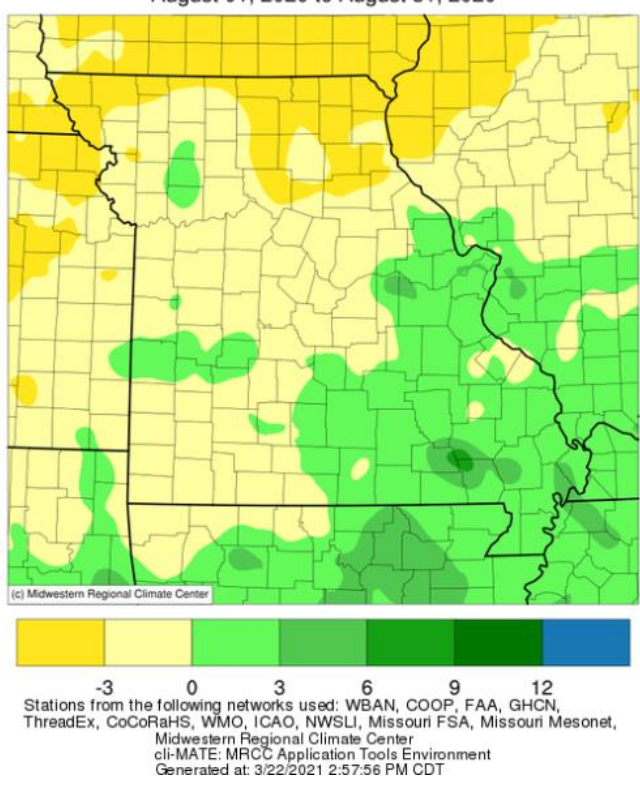

Accumulated Precipitation (in): Departure from 1981-2010 Normals July 01,2020 to July 31,2020

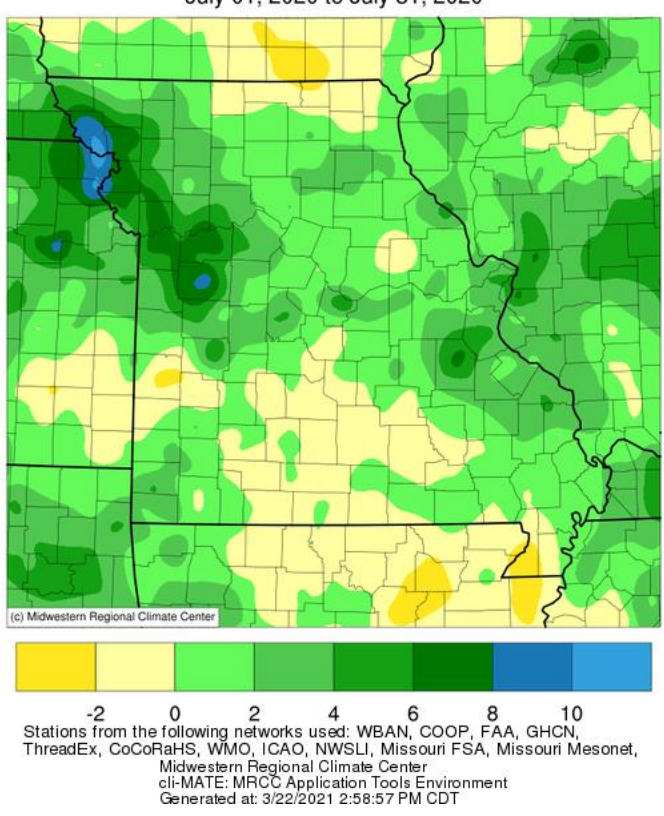

Accumulated Precipitation (in): Departure from 1981-2010 Normals June 01, 2020 to August 31, 2020

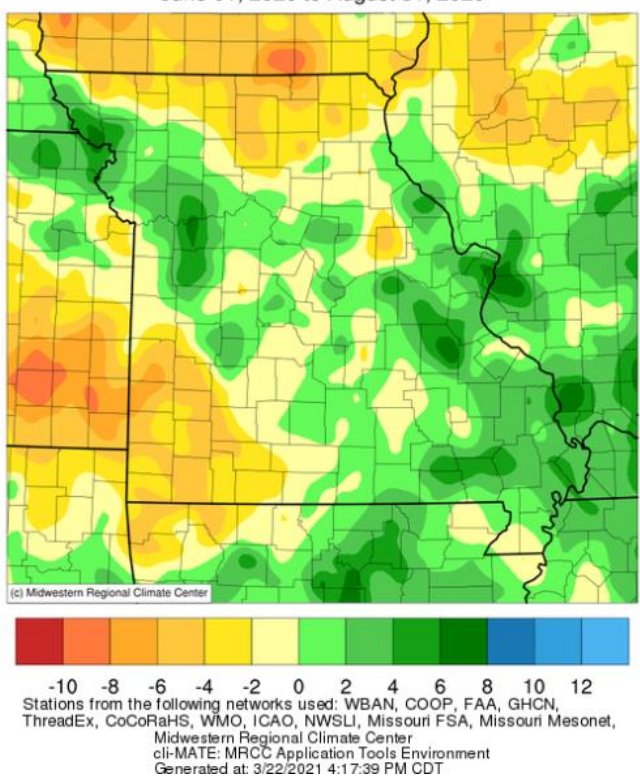

Figure 2.6. Average precipitation, shown in inches, in Missouri between June $1^{\text {st }}, 2020$ to August $31^{\text {st }}, 2020$ and how it differs from the 1981-2010 normal average. Online publication by Midwestern Regional Climate Center (MRCC https://mrcc.illinois.edu 2021). 


\subsection{Literature Cited}

Akem, C.N., and Dashiell, K.E. 1994. Effect of planting date on severity of frogeye leaf spot and grain yield of soybeans. Crop Prot. 13:607-610.

Akem, C.N., Dashiell, K.E., and Uwala, A.C. 1992. Prevalence of frogeye leaf spot of soybean in Nigeria. Int. J. Trop. Plant Dis. 10:181-183.

Athow, K.L., and Probst, A.H. 1952. The inheritance of resistance to frogeye leaf spot of soybeans. Phytopathology 42:660-662.

Bartlett, D.W., Clough, J.M., Godwin, J.R., Hall, A.A., Hamer, M., and ParrDobrzanski, B. 2002. The strobilurin fungicides. Pest Manag. Sci. 58:649662.

Bandara, A. Y., Weerasooriya, D. K., Bradley, C. A., Allen, T. W., and Esker, P. D. (2020). Dissecting the economic impact of soybean diseases in the United States over two decades. PloS one, 15(4), e0231141. https://doi.org/10.1371/journal.pone.0231141

Bernaux, P. 1979. Identification of some soybean diseases in Cameroon. Agron. Trop. 34:301-304.

Boyer, C.N., Smith, A., Harmon, X.L., Lambert, D.M., Kelly, H.Y., Jordan, J., and Newman, M. 2017. Value of damage control with foliar fungicide in soybean production in Tennessee. Agron. J. 109:1573-1581.

Brent, K.J. 2012. Historical perspectives of fungicide resistance. T.S. Thind (Ed.), Fungicide resistance in crop protection: Risk and management, $\mathrm{CABI}$, Wallingford, UK (2012), pp 3-18. 
Corwin, J.A., and Kiebenstein, D.J. 2017. Quantitative Resistance: more than just perception of a pathogen. The Plant Cell 29(4):655-665.

Dashiell, K.E., and Akem, C.N.1991. Yield losses in soybeans from frogeye leaf spot caused by Cercospora sojina. Crop Prot. 10:465-468.

Deising, H.B., Reimann, S., and Pascholatti, S.F. 2008. Mechanisms and significance of fungicide resistance. Brazilian Journal of Microbiology. 39(2): 268-295

Dorrance, A.E., Mills, D., Robertson, A.E., Draper, M.A., Giesler, L., and Tenuta, A. 2007. Phytophthora root stem rot of soybean. Plant Pathology and Microbiology Publications. 86.

Eckert, J.W. 1982. Case study 5: Penicillium decay of citrus fruits. J. Dekker, S.G. Georgopoulos (eds.) Fungicide resistance in crop protection, Pudoc, Wageningen, The Netherlands (1982), pp. 231-250

Farkas, A., and Aman, J. 1940. The action of diphenyl on Penicillium and Diplodia moulds. Palestine Journal Botany Jerusalem Series 2:38-45

Fisher, N., and Meunier, B. 2008. Molecular basis of resistance to cytochrome bc1 inhibitors. FEMS Yeast Res. 8:183-192.

Hartman, G.L., Sinclair, J.B., and Rupe, J.C. 1999. Compendium of soybean diseases. Saint Paul. American Phytopathological Society (APS Press) Jackson-Ziems, T. 2020. What's new in plant pathology. Online publication: https://cropwatch.unl.edu/2020/whats-new-plant-pathology 
Laviolette, F.A., Athow, K.L., Probst, A.H., Wilcox, J.R., Abney, T.S. 1970. Effect of bacterial pustule and frogeye leaf spot on yield of Clark soybean. Crop Sci. 10:410-419.

Lin, B., and Kelly, H. 2018. Frogeye leaf spot of soybean. The Plant Health Instructor. DOI:10.1094/PHI-I-2018-1018-01.

Ma, G.Z. 1994. Review and forecast of study of frogeye leaf spot. Soybean J. $1: 6-7$

Mandadi, K.K., and Scholthof, K.B. 2013. Plant immune responses against viruses: how does a virus cause disease? The Plant Cell, 25(5): 14891505

Markell, S., Berghuis, B., and Hansen, B. 2020. Frogeye leaf spot update (09/24/20). Online publication: https://www.ag.ndsu.edu/cpr/plantpathology/soybean-frogeye-leaf-spot-update-09-24-20

Matsumoto, T., and Tomoyasu, R. 1925. Studies on purple speck of soybean seed. Japanese Journal of Phytopathology 1(6)1-14_1

Mengistu, A., Kelly, H.M., Bellaloui, N., Arelli, P.R., Reddy, K.N., and Wrather, A.J. 2014. Tillage, fungicide, and cultivar effects on frogeye leaf spot severity and yield in soybean. Plant Dis. 98:1476-1484

Mengistu, A., Ray, J.D., Kelly, H.M., Lin, B., Yu, H., Smith, J.R., Arelli, P.R., and Bellaloui, N. 2020. Pathotype Grouping of Cercospora sojina Isolates on Soybean and Sensitivity to Qol Fungicides. Plant Dis. 104(2):373-380. doi: 10.1094/PDIS-02-19-0368-RE. Epub 2019 Dec 16. PMID: 31841377. 
Mian, M.A.R., Boerma, H.R., Phillips, D.V., Kenty, M.M., Shannon, G., Shipe, E.R. Soffes-Blount, A.R., and Weaver, D.B. 1998. Performance of frogeye leaf spot-resistant and-susceptible near-isolines of soybean. Plant Dis. 82:1017- 1021.

Mian, M.A.R., Missaoui, A.M., Walker, D.R., Phillips, D.V., and Boerma, H.R. 2008. Frogeye leaf spot of soybean: a review and proposed race designations for isolates of C. sojina Hara. Crop Sci. 48,14-24.

Mueller, D., Kandel, Y., and Bradley, C. 2018. Frogeye leaf spot fungicide resistance confirmed in lowa soybean. Online publication: https://crops.extension.iastate.edu/cropnews/2018/02/frogeye-leaf-spotfungicide-resistance-confirmed-iowa-soybean

Mwase, F.W., and Kapooria, R.G. 2001. Incidence and severity of frogeye leaf spot and associated yield losses in soybeans in agro-ecological zone II of Zambia. Mycopathologia 149:73-78.

Neves, D.L., Chilvers, M.I., Jackson-Ziems, T.A., Malvick, D.K., and Bradley, C.A. 2020. Resistance to Quinone Outside Inhibitor fungicides conferred by the G143A mutation in Cercospora sojina (causal agent of frogeye leaf spot) isolates from Michigan, Minnesota, and Nebraska soybean fields. Plant Health Prog. 21(4):230-231

Phillips, D.V. 1999. Frogeye leaf spot. in: Compendium of Soybean Diseases, 5th ed. P 43-44. G.L. Hartman, J.C. Rupe, E.J. Sikora, L.L. Domier, J.A. Davis, and K.L. Steffey eds. American Phytopathological Society, St. Paul, MN. 
Phillips, D.V. and Boerma, H.R. 1982. Cercospora sojina race 5: A threat to soybean in the southeastern United States. Phytopathology 71:334-336.

Poag, P.S., Popp, M., Rupe, J., Dixon, B., Rothrock, C., and Boger, C. 2005. Economic evaluation of soybean fungicide seed treatment. Agron. J. 97:1647-1657.

Soares, A.P.G., Guillin, E.A., Borges, L.L., Silva, A.C.T.d., Álvaro, M.R.d., Grijalba, P.E., Gottlieb, A.M., Bluhm, B.H., and Oliveira, L.O.d. 2015. More Cercospora species infect soybean across the Americas than meets the eye. PLOS ONE 10(8):e0133495

Standish, J.R., Tomaso-Peterson, M., Allen, T.W., Sabanadzovic, S., and Aboughanem-Sabanadzovic, N. 2015. Occurrence of Qol fungicide resistance in Cercospora sojina from Mississippi soybean. Plant Dis. $99: 1347-1352$.

Tillet, M. 1755. Dissertation sur la cause qui corrompt et noircit les grains de ble dans les epis; et sur les moyens de prevenir ces accidetns. P. Bruin, Bourdeaux, France.

Walters, H.J. 1980. Soybean leaf blight caused by Cercospora kikuchii. Plant Dis. 64:961-962.

Westphal, A., Abney, T.S., and Shaner, G. 2006. Diseases of soybean: Frogeye leaf spot. Publ. no. BP-131-W. Purdue Ext., West-Lafayette, IN.

Wood, P., and Hollomon, D. 2003. A critical evaluation of the role of alternative oxidase in the performance of strobilurin and related fungicides acting at the Qo site of complex III. Pest Manag. Sci. 59(5)499-511 
Zeng, F., Arnao, E., Zhang, G., Olaya, G., Wullschleger, J., Sierotzki, H., Ming, R., Bluhm, B. H., Bond, J. P., Fakhoury, A. M., and Bradley, C. A. 2015. Characterization of quinone outside inhibitor fungicide resistance in Cercospora sojina and development of diagnostic tools for its identification. Plant Dis. 99:544-550.

Zhang, G. and Bradley, C. 2017. Comparison of quinone outside inhibitor fungicide-resistant and -sensitive isolates of Cercospora sojina. Crop Prot. 94, 59-63.

Zhang, G.R., Newman, M.A., and Bradley, C.A. 2012. First report of the soybean frogeye leaf spot fungus (Cercospora sojina) resistant to Quinone outside Inhibitor fungicides in North America. Plant Dis. 96(5):767

Zhang, G., Pederson, D.K., Phillips, D.V., and Bradley, C.A. 2012. Sensitivity of Cercospora sojina isolates to quinone outside inhibitor fungicides. Crop Prot. 40:63-68

Zhang, G., Allen, T.W., Bond, J.P., Fakhoury, A.M., Dorrance, A.E., Weber, L., Faske, T.R., Giesler, L.J., Hershman, D.E., Kennedy, B.S., Neves, D.L., Hollier, C.A., Kelly, H.M., Newman, M.A., Kleczewski, N.M., Koenning, S.R., Thiessen, L.D., Mehl, H.L., Zhou, T., Meyer, M.D., Mueller, D.S., Kandel, Y.R., Price III, P.P., Rupe, J.C., Sikora, E.J., Standish, J.R., Tomaso-Peterson, M., Wise, K.A., and Bradley, C.A. 2018. Widespread occurrence of quinone outside inhibitor fungicide-resistant isolates of Cercospora sojina, causal agent of frogeye leaf spot of soybean, in the United States. Plant Health Prog. 19:295-302. 


\section{CHAPTER 3. Air Sampling for Cercospora sojina Spores in Missouri}

\section{Fields}

With soybean diseases accounting over $\$ 4.5$ billion USD in lost yield annually in the United States (Bandara et al. 2020), novel techniques that can identify the presence of plant pathogens in season have the potential to play a critical role in the future of farming. Although it is impossible to $100 \%$ predict when airborne spores will be present in an area due to host availability, it is feasible to develop and design a forecast modeling system to track pathogenic spore movement based on previous spore distribution (Venette et al. 2010; Jackson and Bayliss 2011). Current fungal disease prediction models rely primarily on environmental parameters with the assumption that the pathogen is or will become readily present. Prediction models for wheat scab (http://www.wheatscab.psu.edu), apple scab, Karnal bunt and Asian soybean rust are some such models that have been widely used and are reliable (Aylor 1998; Stansbury et al. 2002; Pan et al. 2006; Jackson and Bayliss 2011).

Notably, the wheat scab prediction model utilizes temperature and relative humidity to predict disease risk in areas where wheat is grown. Risk levels are based on environmental factors coupled with variety resistance to Fusarium head blight (Jackson and Bayliss 2011).

Several major fungal plant pathogens spread by spores are dispersed via wind (Gregory 1962; Chen et al. 2018). Wind dispersal can result in long distance dissemination of spores to different cities, countries or even continents than their origination point (Morris et al. 2013; Gregory 1952; West and Kimber 2015). Air 
samplers can be an effective way to alert to the presence of a fungal pathogen before symptoms are observed in the field (West and Kimber, 2015; Chen et al. 2018). An example of long-distance spread is the appearance of the Asian soybean rust (Phakopsora pachyrhizi) in the United States in 2004 which likely entered the U.S. via winds from hurricane Ivan that carried spores from Colombia (Rup and Sconyers 2008; Isard et al. 2011; Chen et al. 2018).

Spore traps are an important tool for the enhancement of pathogenic prediction models. Continuous in-field spore sampling is the only way to confirm the presence of a pathogen in a field before disease symptoms are apparent (Jackson and Bayliss, 2011). Early detection and quantification of airborne pathogens could reduce fungicide application costs by reducing frequency and number of applications and can contribute to managing fungicide resistance (Klosterman et al. 2016). Adverse weather conditions including rain and wind can affect spore dispersal and viability regardless of the collection mechanism used (Chen et al. 2018) and must be addressed. Heavy rainfall can affect air sampling mechanism functionality by contributing to improper spore load deposition. Although rain droplets can assist with the spread of windborne pathogens and help pathogen germination and infection by providing water, they can also disturb the spore's ability to attach on the host (Chen et al. 2018). Being able to detect and quantify airborne pathogenic pathogens early on could reduce costs associated with fungicidal disease control by reducing frequency of applications and can contribute to managing fungicide resistance (Klosterman et al. 2016). 
Pest predictions can provide farmers with advance knowledge of the pathogens they may face but completely predicting when pathogenic spores can enter a specific zone is close to impossible (Jackson and Bayliss 2011). However, with a multitude of different types of spore traps available, two primary issues arise when selecting for the best trap for disease modeling and spore collection: cost and efficiency. In this study, our goals were: i) to analyze the efficacy of collecting and identifying fungicide-resistant Cercospora sojina from spore traps using different spore trap types, and ii) compare the effectiveness of different non-commercial spore collection traps.

\subsection{Materials and Methods}

i. Spore Traps

Three different spore traps were assembled and deployed in Missouri soybean fields in the years of 2019 and 2020 (Figure 3.1) The three traps were non-commercial traps: one was an active spore trap (AC), built according to the protocol from Gadoury and MacHardy (1983), one was a semi-passive (SP) trap modified from Hagler et al. (2002), and the third a passive (P) trap.

\section{ii. Spore Trap Construction}

The active spore trap was built based on the volumetric spore trap designed by Gadoury and MacHardy (1983) (Figure 3.2). The Modified Gadoury and MacHardy (MGM) sampler differed from the design by replacing the interior timing mechanism with a Dickson SC367 S/N 08197326 (Dickson data; Addison, IL) and the turbine with a 40mm PC cooler fan (Cooler Guys; Kirkland, WA). For sample collection, a 3M 850 polyester film low-pressure tape (3M Company, 
Saint Paul, MN) was used in tandem with a permanent double-sided Scotch tape (3M Company, Saint Paul, MN), where the double sized tape was used as an anchor to secure the low-pressure tape in place. When the tape used on the collection head (Figure $3.2 \mathrm{~B}$ ) to collect material was removed, it was placed in a 50mL Falcon tube (Fisher Scientific Company LLC, Waltham, MA) to be transported and stored at $-4^{\circ} \mathrm{C}\left(24.8^{\circ} \mathrm{F}\right)$ until DNA was extracted.

The modified Hagler et al. (2020) SP spore trap (Figure 3.3) was designed using a PVC fin (Fig. 9.A) shaped like a triangle $(11.4 \mathrm{~cm}$ wide and $6.4 \mathrm{~cm}$ tall) placed on the top of the PVC body (Figure 3.3 B). The fin both served to direct the spore trap to be in line with air currents and to provide stability to the setup. The fan used for semi-active air intake was a 40mm PC fan (Cooler Guys) placed in the back of the PVC body. At the back end of the PVC body away from the PC fan, a slit approximately one centimeter from the end was made to fit a regular glass slide (Figure 3.3A) (Fisher Scientific Company LLC, Waltham, MA) covered with double sided permanent Scotch tape (3M Company). A piece of 3M 850 polyester film low-pressure tape (3M Company) tape was placed over the double-sided tape, facing the fan to collect spores. A metal mesh (Figure 3.3 B) was fastened to the PVC pipe at the back end nearest the glass slide, with regular duct tape to protect the apparatus from foreign objects. The setup was attached to a vertical PVC tube (Figure 3.3 A) connected on the bottom of the trap to support the spore trap.

Both SP and AC traps were powered by an Outlast Battery, SB1280 12V8AH (Outlast Battery; Manila, Philippines) protected by a NOCO HM082 
battery box (The NOCO company; Cleveland, $\mathrm{OH}$ ). The battery was connected to a Suner Power BC-20W poly solar panel (Suner power; Shezhen, China) to ensure the traps would always be powered.

The P spore trap was a modified, slightly larger version of the SP trap. Instead of a fan, a $10 \mathrm{~cm}$ wide funnel (Figure 3.4) was placed inside one end of the $10 \mathrm{~cm}$ diameter PVC pipe body to direct the wind toward a regular glass slide (Fisher Scientific Company LLC). The glass slide was fastened to the metal mesh using Velcro-style Command ${ }^{\mathrm{TM}}$ strips (3M). The metal mesh was held to the PVC tube using a 4.5-inch steel clamp. Polyester film low-pressure tape (850 polyester film tape, 3M) was used for spore collection and was secured to the front of the glass slide using double sided permanent Scotch tape (3M) in the same manner as the SP head. The setup was attached to a vertical PVC tube connected on the bottom of the trap to support the spore trap.

Both SP and P spore traps were installed on $1.25 \mathrm{~cm}$ wide, $1.5 \mathrm{~m}$ metal rods inserted on their vertical PVC tube. The AC trap was mounted on a metal "T" post using two steel clamps tightly secured around the vertical PVC tube and the metal post (Figure 3.2 A). Both metal rod and the metal "T" post were buried one foot in the ground. The aperture opening for all spore traps were approximately $1.5 \mathrm{~m}$ above the ground.

iii. C. sojina DNA Recovery and Analysis

v. Glass slides from the SP and P spore traps and tape from the AC traps were collected weekly. Samples were kept frozen prior to processing. For DNA analysis, the $3 \mathrm{M} 850$ polyester film tape was removed from each glass slide, cut 
into $0.5 \mathrm{~cm}$ pieces and added to a $2 \mathrm{~mL}$ tube. The tape collected from the AC trap was removed from the $50 \mathrm{~mL}$ Falcon tube, cut in $0.5 \mathrm{~cm}$ by $0.5 \mathrm{~cm}$ pieces and placed in a $2 \mathrm{~mL}$ tube. DNA was extracted using a method modified from Hall et al. (2017) by dividing the quantities of all reagents used by 10 due to sample size. Following DNA extraction, samples were analyzed using a NanoDrop One (Thermo Scientific, Waltham, MA) to quantify the level of genomic DNA. For this study, DNA levels measured with the NanoDrop of $10 \mathrm{ug} / \mathrm{ml}$ were considered satisfactory, and samples that had a satisfactory level of uncontaminated DNA (Table 3.1) were selected and run using PCR. PCR conditions for analysis were run in $50 \mu \mathrm{L}$ reaction volumes using a 6325 Mastercycler Pro thermal cycler that contained $10 \mu \mathrm{L}$ of Green GoTaq Flexi Buffer, $1 \mu \mathrm{L}$ of GoTaq Hot Start Polymerase $(5 \mathrm{u} / \mu \mathrm{l}), 1 \mu \mathrm{L}$ of nucleotide mix, and $2 \mu \mathrm{L}$ of $\mathrm{MgCl}_{2}$ (provided by Promega Corp., Madison, WI). For each reaction, $2 \mu \mathrm{L}$ of forward and $2 \mu \mathrm{L}$ of reverse primers (100 $\mu \mathrm{M}$ solution), $1 \mu \mathrm{L}$ of the DNA template and $31 \mu \mathrm{L}$ of deionized water were added to each well. Primers used were the same ones used on chapter 2 , section iv, and identified in Table 2.2. Conditions for thermal cycler were set following Zeng et al. (2015) protocol: denaturation of DNA at $95^{\circ} \mathrm{C}$ lasting 2 minutes, followed by DNA was amplification for 30 cycles for 30 seconds with a denaturation phase of $95^{\circ} \mathrm{C}$, annealing at $50^{\circ} \mathrm{C}$ for 30 seconds, and extension at $72^{\circ} \mathrm{C}$ for 1 minute. To complete the PCR reaction, final DNA extension lasted $5 \min$ at $72^{\circ} \mathrm{C}$. 


\subsection{Results}

The DNA amounts collected and measured via the NanoDrop increased as the season progressed, indicating a higher spore collection late in the growing season which matched the crew's visual observations of disease progression in the fields where the spore traps or located (Table 3.1). With the increases in DNA concentration over the collection period, 17 samples had sufficient DNA to run PCR analysis for the presence of $C$. sojina and potential fungicide resistance in the dominant G143A mutation. However, C. sojina was not detected in any samples recovered from the spore traps in this study possibly due to low DNA levels or the presence of mixed genetic material. A $1 \%$ agarose gel was run to test for the presence of $C$. sojina; however, no bands were not detected (Figure 3.5). Due to negative results after electrophoresis, the PCR test was repeated 3 times in order to ensure veracity of results.

The spore traps located in Graves-Chapple were the only set that presented nucleic acids reading between 5 and $8 \mathrm{ng} / \mu \mathrm{L}$ in the NanoDrop, as shown on Table 3.1. The highest concentration collected by the NanoDrop was $11.79 \mathrm{ng} / \mu \mathrm{L}$ and was collected at week 18 in 2020, or around early September, which corresponded to late reproductive stages of soybean in that region.

\subsection{Discussion}

In this study, the DNA concentration collected from the spore traps was minimal with only 17 samples containing ample levels of DNA for PCR analysis. The low levels of DNA collected can be considered a limitation of spore trapping as it makes harder to get firm results. The samples run via PCR were 
inconclusive when compared with C. sojina wild-type and G143A fungicide resistance mutation primers. As most traps collect via wind, they also collect dust, small insects and other unwanted material, not just spores and DNA filled material. This does not signify that spore traps do not work; it just shows that more work should be done to ensure the functionality of the machinery and construction of traps throughout the season. Also, location of the traps is a critical factor in determining their collection potential, especially in regard to if they will be deployed close to fields where the host and pathogen are present. In this research, the non-commercial passive spores traps at the GC research station had a better result in collecting DNA filled samples than the other types of noncommercial traps at the same location, or at any other locations in this study.

It is important to note that there are successful examples of spore traps being used in agriculture. A few examples are those used for identification of rust in cool-season grasses at the Pacific Northwest states of Oregon and Washington (Dung et al. 2018) and the early identification of Fusarium circinatum in North Florida (Quesada et al. 2018). These examples demonstrate how useful and beneficial spore traps can be for the identification of pathogens in crop fields. While beneficial for some pathogens, it is not known if spore size causes a difference in the effectiveness of spore collection. C. sojina spores are very small and potentially making their trapping can be difficult. With a small spore size, they could potentially blow away more easily and may not attach to the collection tape of the spore trap. This is especially true with constructed spore traps such as those used in this study. 
Additionally, the weather in Missouri was not optimal for the development of FLS in 2019 or 2020 and may have affected the presence of the $C$. sojina pathogen. In 2019, the GC and B regions were wet early in the season (Figure 3.5) (Midwestern Regional Climate Center), delaying soybean planting meaning soybean plants reached the optimal developmental stage for $C$. sojina infection later than normal. By the time the reproductive growth stage 3 (early pod development) was reached, ample moisture was not present for FLS development. In 2020, the regions where the B and DC research stations are located did not have environmental conditions conducive for the development of FLS. Environmental conditions were too dry and temperatures were average but not optimal for the spread of FLS (Figure 3.6) (Midwestern Regional Climate Center), decreasing the likelihood of spore presence in these regions.

As with any emerging technology, more studies need to be conducted over multiple environments in order to utilize spore traps as a reliable collection tool. Spore traps have the potential to act as alert systems and speed up the identification of pathogens as they enter new areas. Early identification of pathogens can improve disease management programs by increasing prediction accuracy. Proper identification of the pathogens also allows for the reduction of fungicide resistance in areas where it may not yet be present. Additionally, spore traps may be used to detect fungicide resistance development in new pathogens in areas where resistance was not previously identified. Selecting the right type of spore trap for the style of sampling needed, environmental conditions and 
sampling timings is key for sampling success (Aizenberg et al. 2000; Jackson and Bayliss 2011).

Importantly, just collecting spores is not enough as proper identification is vital. Using DNA extraction and analysis is critical to understanding more about the collected spores and their genetics and how to properly act. Unfortunately, as mentioned above, the low levels of DNA collected from spore traps made genomic identification of fungicide resistant isolates difficult as isolated DNA did not resulted in a positive match to the $C$. sojina wild type or fungicide-resistant mutant primers. Possible explanations include: i) C. sojina may have been present though in a mixed sample which potentially interfered with the ability of positively identifying the pathogen or ii) that low to nonexistent levels of $C$. sojina DNA were present in the collected samples. Therefore, it is important to use alternative methods to identify fungicide resistance development in pathogens. 


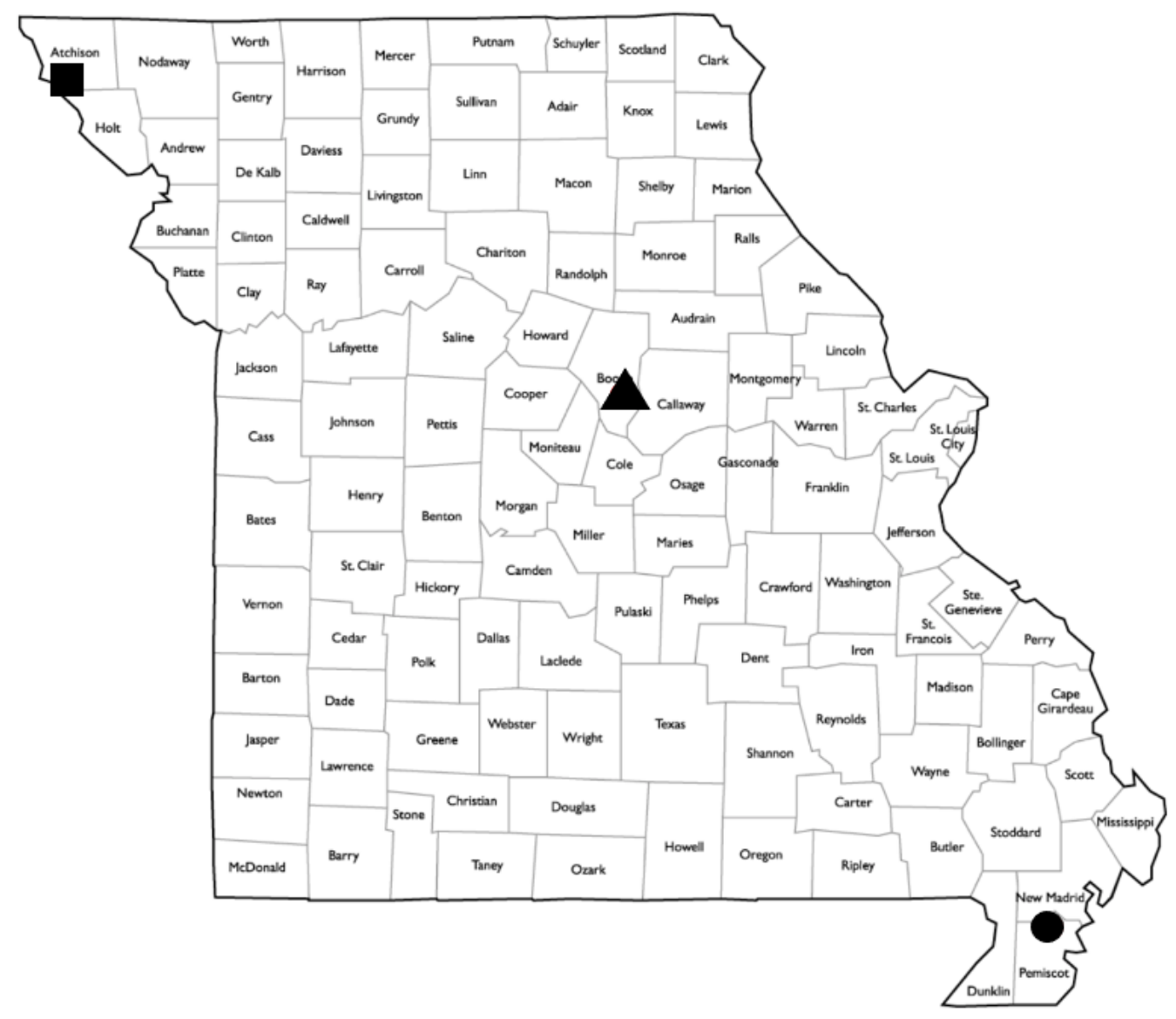

Figure 3.1. Distribution of spore traps deployed in Missouri. Fisher Delta Research Center (DC), Portageville, MO - circle; Bradford Research Center (BR), Columbia, MO - triangle; Graves-Chapple Research Center (GC), Rock Port, MO - square.

The spore trap locations represented a diverse cross section of the state both geographically and agronomically. Known fungicide resistance to $C$. sojina had previously been detected near the DC research Station (Bradley et al. 2012). The BR and GC sites were selected to monitor potential spread of fungicide resistant $C$. sojina into previously undocumented soybean producing areas with known presence of the FLS pathogen. 

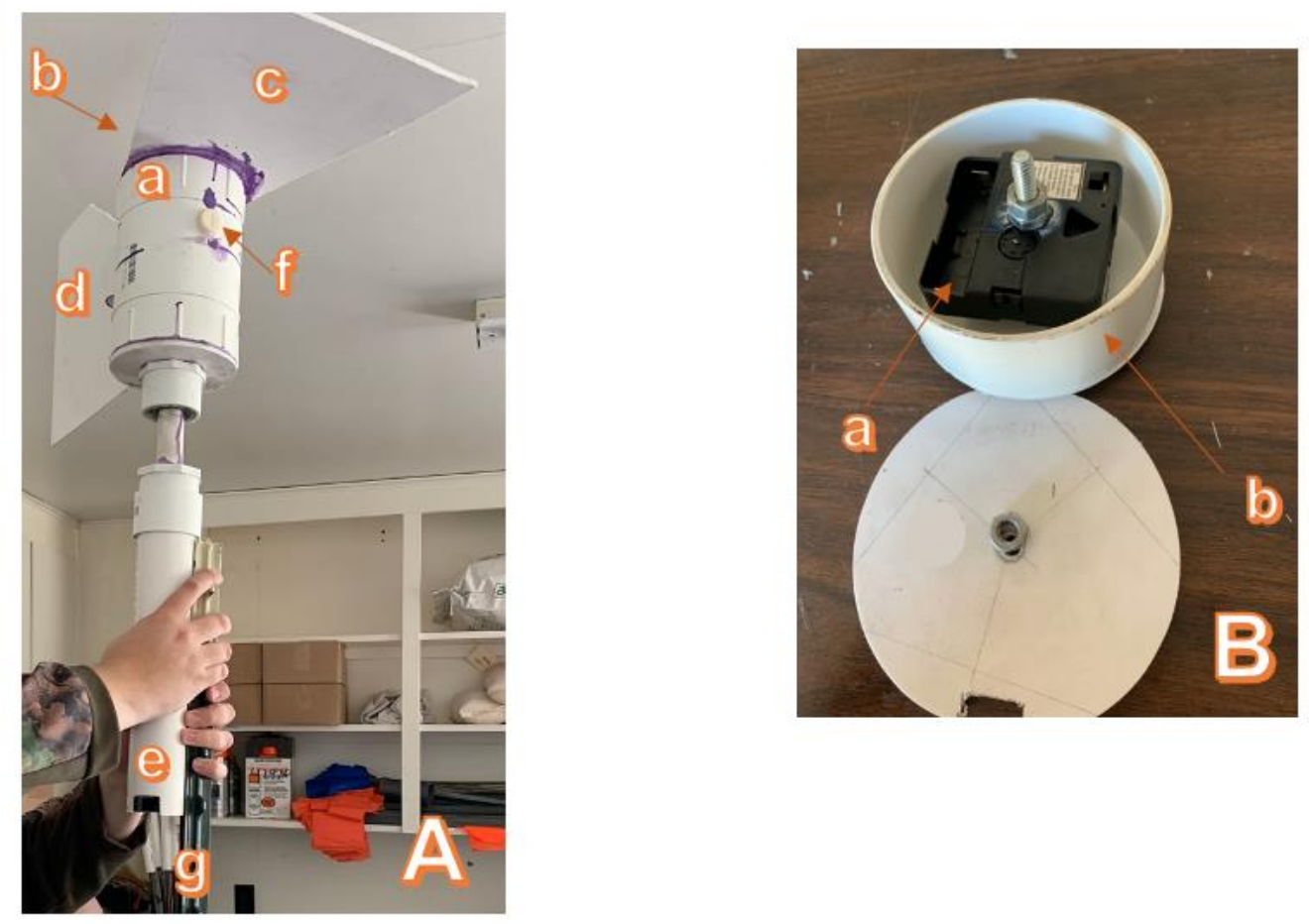

Figure 3.2. Panel A shows the Modified Gadoury and MacHardy sampler built of PVC which consisted of: (a) a PVC body, (b) a collection head - shown in detail on panel B. Both the PVC fin (c) and tail (d) were added to improve the stability of the sampler and improve sampler movement by wind. The computer fan (e) acted as a turbine by sucking air through collection hole (f). Metal ' $T$ ' post (g) was used for trap sustainability. Panel B depicts the collection head with a Dickson rotating mechanism inside (a) the collection head. Arrow (b) shows where low-pressure tape was secured. 

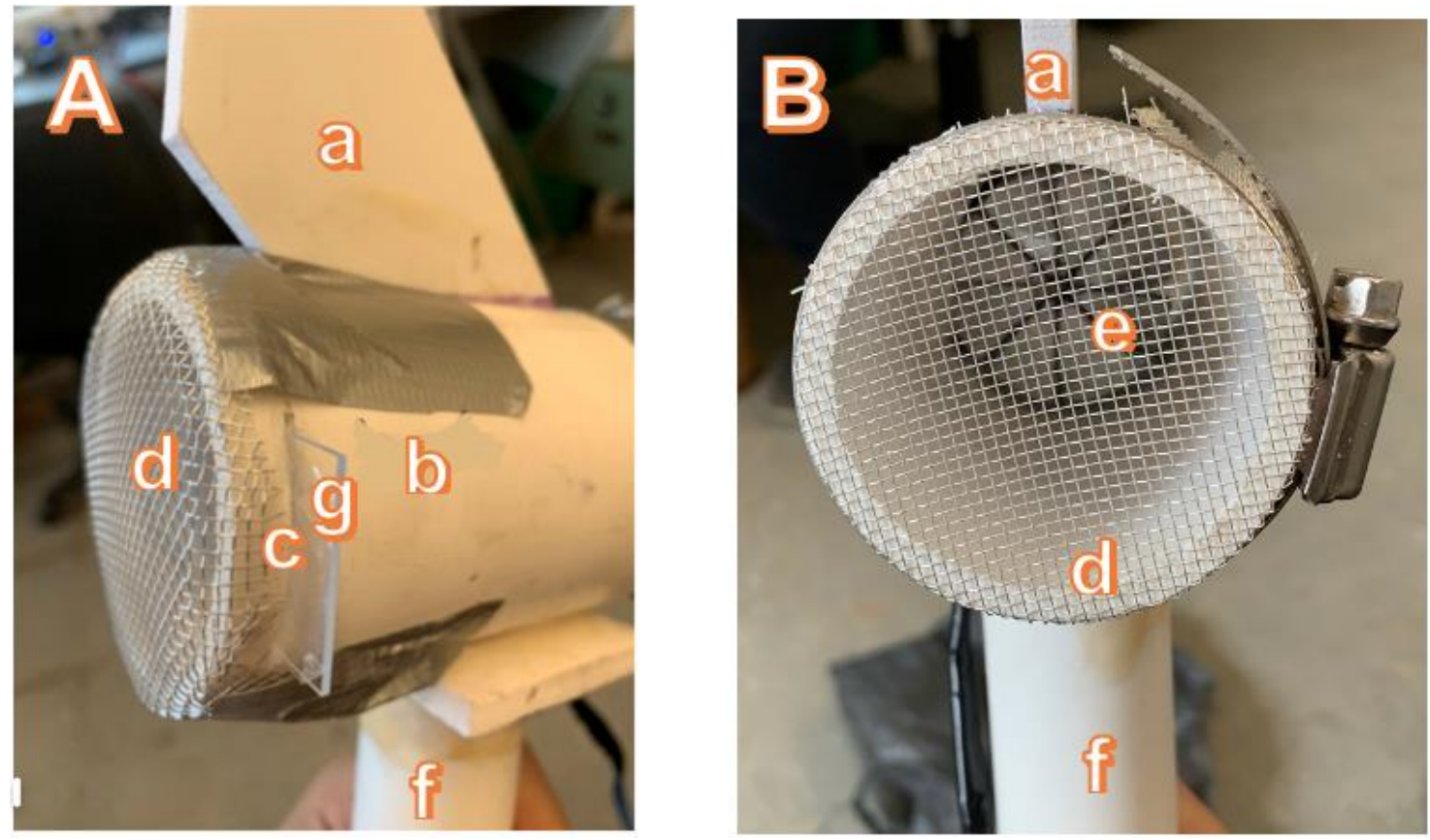

Figure 3.3. A side view (A) and back view (B) from the SP spore trap, built from PVC pipe containing a fin (a), PVC tube as body (b), opening for the glass slide to collect spores (c), metal mesh (d) to prevent foreign material from entering, supportive PVC tube (f), and PC fan in the background (e). The glass slide (g) had two layers of tape, first a layer of double-sided tape followed by a layer of a low-pressure tape. 


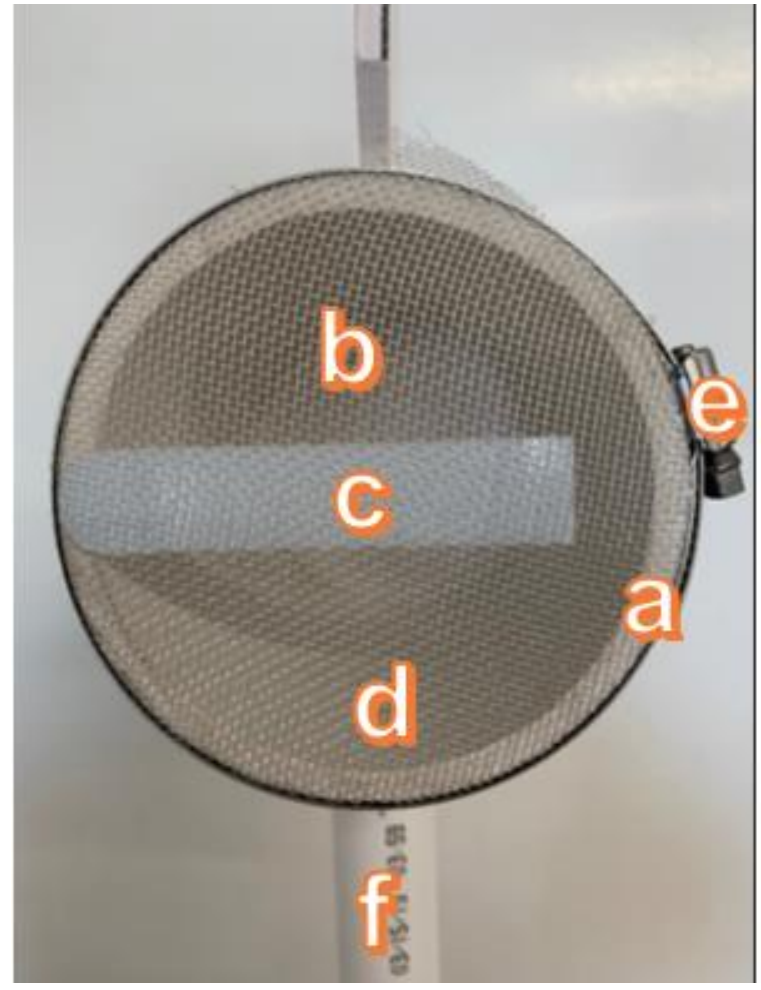

Figure 3.4. Passive spore trap containing a PVC body (a), PVC fin, and funnel in the background (b), directing wind to a glass slide that has two layers of tape, first a layer of double-sided tape followed by a layer of a low-pressure tape connected to metal mesh via Velcro tape (c), metal mesh (d) secured by a metal hose clamp (e). 


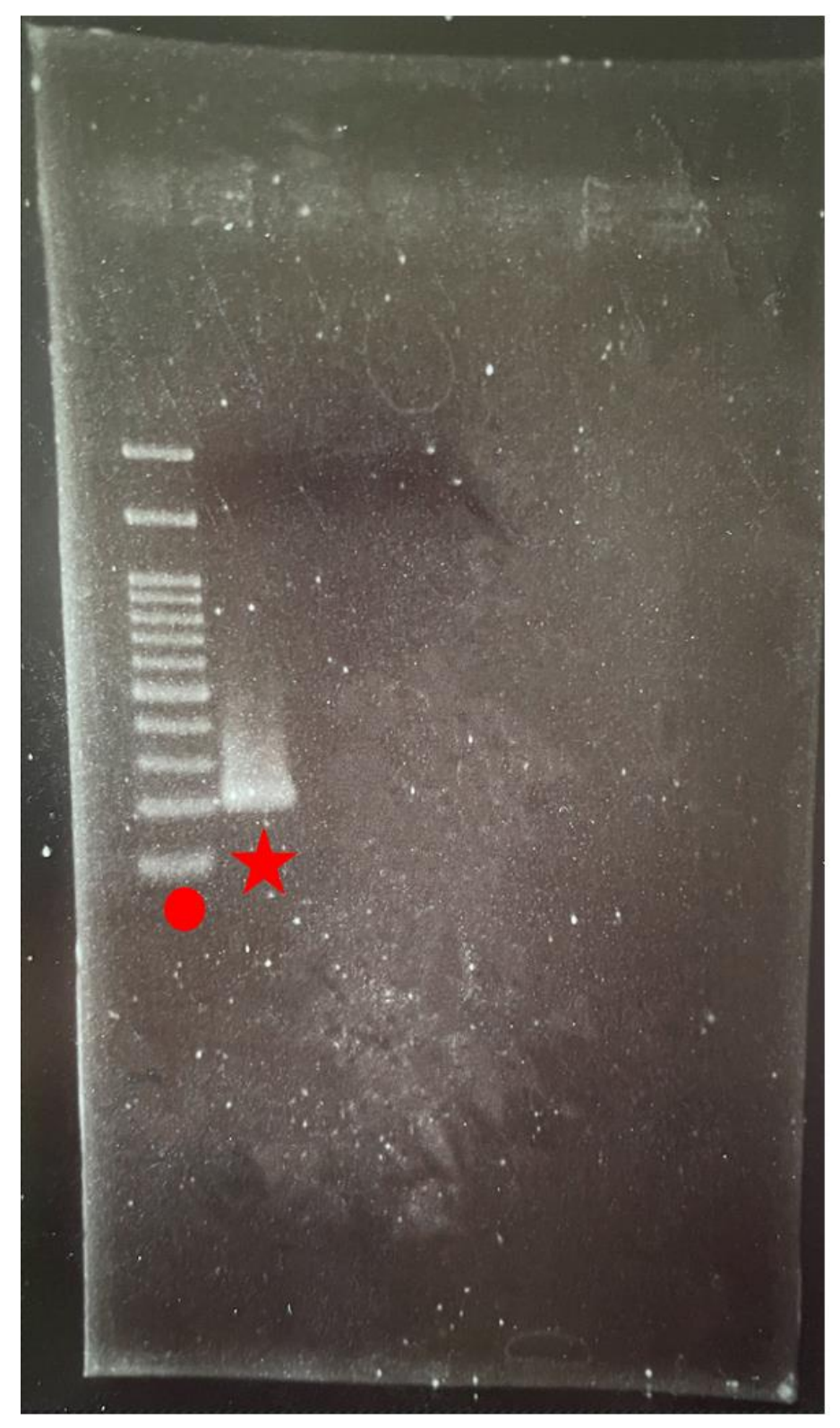

Figure 3.5. Agarose gel showing PCR results from SP spore trap samples collected from the GC location where the red circle symbolizes the DNA ladder and the red star the positive control. 
Average Temperature $\left({ }^{\circ} \mathrm{F}\right)$ : Departure from 1981-2010 Normals June 01, 2019 to August 31, 2019

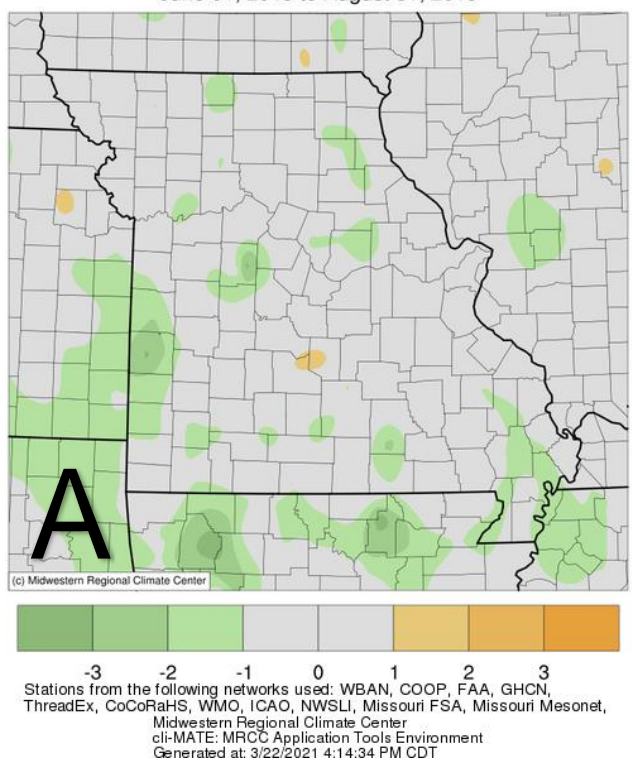

Accumulated Precipitation (in): Departure from 1981-2010 Normals June 01, 2019 to August 31, 2019
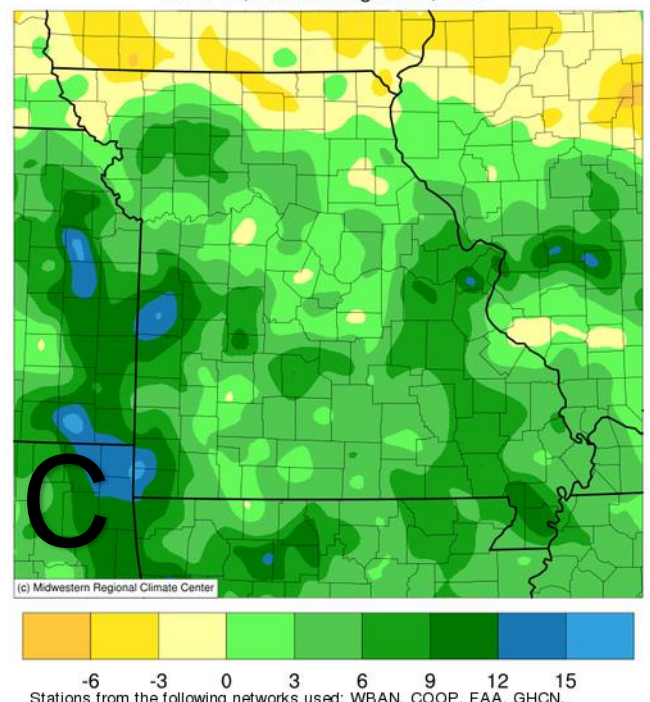

Stations from the following networks used: WBAN, COOP, FAA, GHCN, av Midwestern Regional Climate Center
cli-MATE: MRCC Application Tools Environment
Generated

Average Temperature $\left({ }^{\circ} \mathrm{F}\right)$ : Departure from 1981-2010 Normals June 01,2020 to August 31, 2020
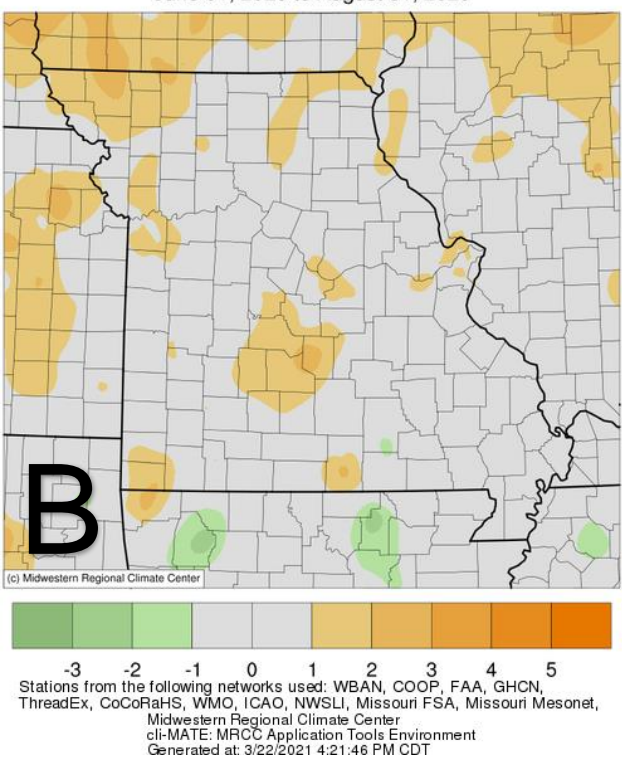

Accumulated Precipitation (in): Departure from 1981-2010 Normals June 01,2020 to August 31, 2020

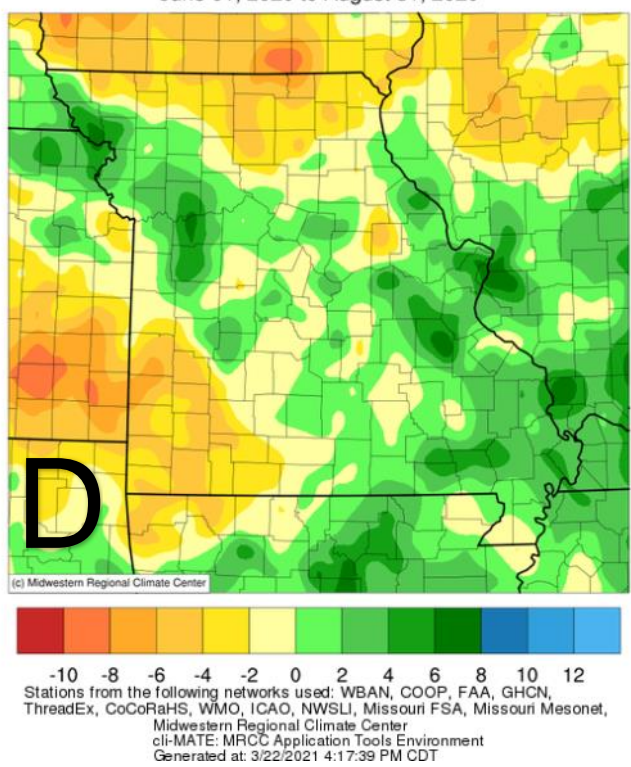

Figure 3.6. A and C represent 2019 average temperature, shown in Fahrenheit, and precipitation in Missouri between June $1^{\text {st }}$ and August $31^{\text {st }}$ and how it differs from the 1981-2010 normal average; B and D represent 2020 average temperature, shown in Fahrenheit, and precipitation in Missouri between June $1^{\text {st }}$ and August $31^{\text {st }}$ and how it differs from the 1981-2010 normal average. Online publication by Midwestern Regional Climate Center. (MRCC https://mrcc.illinois.edu 2021). 


\begin{tabular}{|c|c|c|c|c|c|c|c|c|c|c|c|c|c|c|c|c|c|c|c|}
\hline \multirow{2}{*}{\multicolumn{2}{|c|}{ Type of Spore Trap }} & \multicolumn{18}{|c|}{ COLLECTION WEEK NUMBER } \\
\hline & & \multicolumn{3}{|c|}{15} & \multicolumn{3}{|c|}{16} & \multicolumn{3}{|c|}{17} & \multicolumn{3}{|c|}{18} & \multicolumn{3}{|c|}{19} & \multicolumn{3}{|c|}{20} \\
\hline YEAR & LOCATION & & & & & & & & & & & & & & & & & & \\
\hline 2019 & BR & 0 & 0 & 0 & 0 & 0 & 0 & 0 & 0 & 0 & 0 & 0 & 0 & . & . & & . & . & \\
\hline 2019 & DC & 0 & 0 & 0 & 0 & 0 & 0 & 0 & 0 & 0 & 0 & 0 & 0 & 0 & 0 & 0 & 0 & 0 & 0 \\
\hline 2020 & DC & 0 & 0 & 0 & 0 & 0 & 0 & 0 & 0 & 0 & 0 & 0 & 0 & 0 & 0 & 0 & . & . & \\
\hline
\end{tabular}

Table 3.1. Location from samples that met satisfactory levels of DNA (at least $10 \mathrm{ug} / \mathrm{mL}$ ) during the 2019 and 2020 collection season, and which spore trapping mechanism they were collected from. Where GC = Graves Chapple Research Station; BR = Bradford Research Station; DC = Delta Fisher Center Research Station. Spore trap types include: $\mathrm{P}=$ Passive $; \mathrm{SP}=$ Semi-passive $;$ and $\mathrm{AC}=$ Active 


\subsection{Literature Cited}

Aylor, D.E. 1998. The aerobiology of apple scab. Plant Dis. 82: 838- 849

Bandara, A. Y., Weerasooriya, D. K., Bradley, C. A., Allen, T. W., and Esker, P. D. (2020). Dissecting the economic impact of soybean diseases in the United States over two decades. PloS one, 15(4), e0231141. https://doi.org/10.1371/journal.pone.0231141

Chen, W., Hambleton, S., Seifert, K.A., Carisse, O., Diarra, M.S., Peters, R.D., Lowe, C., Chapados, J.T., and Lévesque, C.A. 2018. Assessing performance of spore samplers in monitoring aeromycobiota and fungal plant pathogen diversity in Canada. Appl. Environ. Microbiol. 1:84(9):e02601-17

Dung, J.K.S., Scott, J.C., Cheng, Q., Alderman, S.C., Kaur, N., Walenta, D.L., Frost, K.E., and Hamm, P.B. 2018. Detection and quantification of airborne Claviceps purpurea sensu lato ascospores from Hirst-type spore traps using real-time quantitative PCR. Plant Dis. 102:2487:2493

Gadoury, D.M., and MacHardy, W.E. 1983. A recording volumetric spore trap. Phytopathology. 73:1526-1531

Gregory, P.H. 1952. Spore content of the atmosphere near the ground. Nature. 170(4325):475-7

Gregory, P.H. 1962. The microbiology of the atmosphere. Soil Sci. 94:349. 
Hagler, J.R., Machtley, S.A., and Leggett, J.E. 2002. Parasitoid mark-releaserecapture techniques $-\mathrm{I}$. Development of a battery-operated suction trap for collecting minute insects. Biocontrol Sci. and Tech. 12:653-659

Isard, S., Barnes, C., Hambleton, S., Ariatti, A., Russo, J., Tenuta, A., Gay, D., Szabo, L. 2011. Predicting soybean rust incursions into the North American continental interior using crop monitoring, spore trapping, and aerobiological modeling. Plant Dis. 95:1346-1357

Jackson, S.L. and Bayliss, K.L. 2011.Spore traps need improvement to fulfil plant biosecurity requirements. Plant Pathology. 60:5. doi.org/10.1111/j.13653059.2011.02445.x

Klosterman, S.J., Anchieta, A., McRoberts, N., Koike, S.T., Subbarao, K.V., Voglmayr, H., Choi, Y.J., Thines, M., and Martin, F.N. 2016. Coupling Spore Traps and Quantitative PCR assays for detection of Downy Mildew pathogen of spinach (Peronospora effusa) and beet ( $P$. schachtii). Phytopathology. 104(12): 1349-1359

Morris, C.E., Sands, D.C., Glaux, C., Samsatly, J., Asaad, S., Moukahel, A.R., Gonçalves, F.L.T., Bigg, E.K. 2013. Urediospores of rust fungi are ice nucleation active at $>-10^{\circ} \mathrm{C}$ and harbor ice nucleation active bacteria. Atmospheric Chemistry and Physics. 13:4223-4233.

Pan. Z., Yang, X.B., Pivonia, S., Xue, L., Pasken, R., Roads, J. 2006. Long-term prediction of soybean rust entry into the continental United States. Plant Dis. 90: $840-846$ 
Quesada, T., Hughes, J., Smith, K., Shin, K., James, P., and Smith, J. 2018. A low-cost spore trap allows collection and real-time PCR quantification of airborne Fusarium circinatum spores. Forests 9(10):586

Rupe, J., and Sconyers, L. 2008. Soybean Rust. The Plant Health Instruc. DOI: 10.1094/PHI-I-2008-0401-01

Stansbury, C.D., McKirdy, S.J., Diggle, A.J., Riley, I.T. 2002. Modeling the risk of entry, establishment, spread, containment, and economic impact of Tilletia indica, the cause of Karnal bunt of wheat, using an Australian context. Phytopathology. 92: 321-331

Venette, R.C., Kriticos, D.J., Magarey, R.D., Koch, F.H., Baker, R.H.A., Worner, S.P. et al. 2010. Pest risk maps for invasive alien species: a roadmap for improvement. BioScience 60: 349-362.

West, J., and Kimber, R. 2015. Innovations in air sampling to detect plant pathogens. Ann. Appl. Biol. 166:4-17. doi:10.1111/aa 